\title{
Modernization of Technical Requirements for Licensing of Advanced Non-Light Water Reactors: Final Project Report
}

Wayne L Moe, Amir Afzali

March 2020

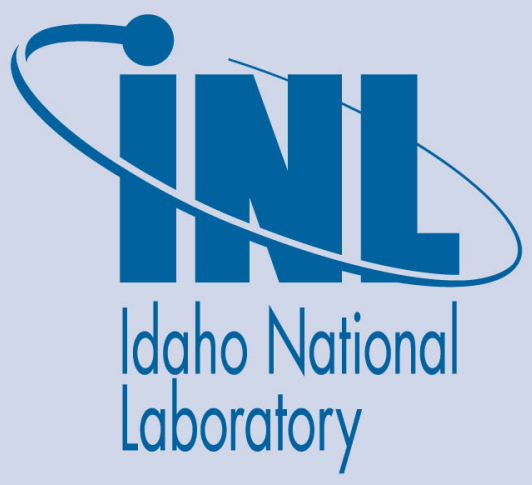

The INL is a U.S. Department of Energy National Laboratory operated by Battelle Energy Alliance 


\title{
Modernization of Technical Requirements for Licensing of Advanced Non-Light Water Reactors: Final Project Report
}

\author{
Wayne L Moe, Amir Afzali
}

March 2020

Idaho National Laboratory Idaho Falls, Idaho 83415

http://www.inl.gov

Prepared for the

U.S. Department of Energy

Under DOE Idaho Operations Office

Contract DE-AC07-05ID14517 


\section{$\mathcal{1}$ \\ Southern Company}

Modernization of Technical Requirements

for Licensing of Advanced Non-Light Water Reactors:

Final Project Report

Document Number

SC-29980-105 Rev 1

March 2020

Prepared for:

U.S. Department of Energy (DOE)

Office of Nuclear Energy

Under DOE Idaho Operations Office

Contract DE-AC07-05ID14517 


\section{$\Delta$ \\ Southern Company}

Modernization of Technical Requirements

for Licensing of Advanced Non-Light Water Reactors:

Final Project Report

Document Number

SC-29980-105 Rev 1

Issued by:

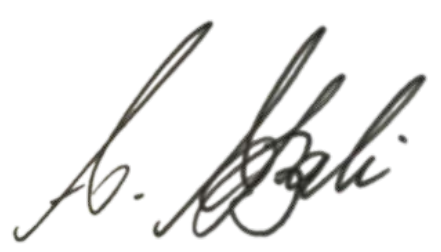

Amir Afzali

Next Generation Licensing and Policy Director

Southern Company Services

\section{$3 / 22 / 2020$}

Date 


\section{AUTHORS' NOTE}

Much of this final report from the Licensing Modernization Project team, particularly historical and project background content, is adapted from INL/EXT-18-46151 "Licensing Modernization Project for Advanced Reactor Technologies: FY 2018 Project Status Report, September 2018." The authors of this report would like to recognize and thank INL/EXT-18-46151 lead author Mr. Wayne Moe of Idaho National Laboratory Regulatory Development for this foundational work. 


\section{TABLE OF CONTENTS}

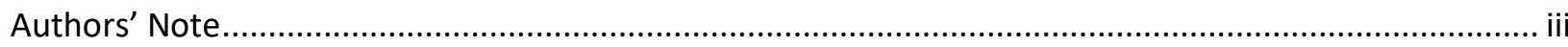

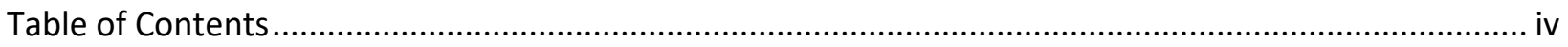

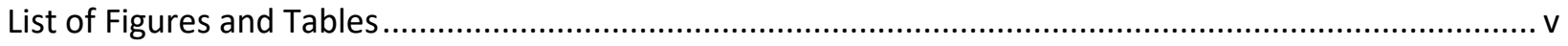

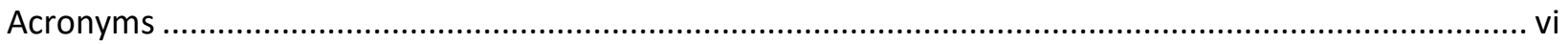

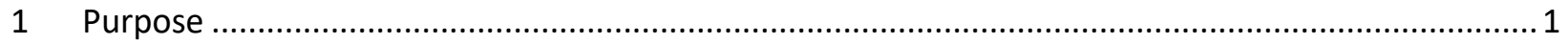

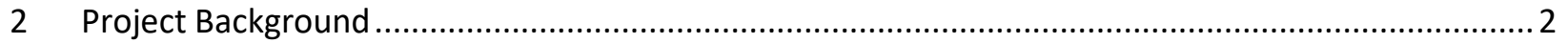

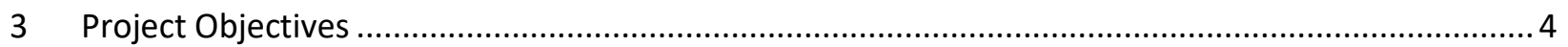

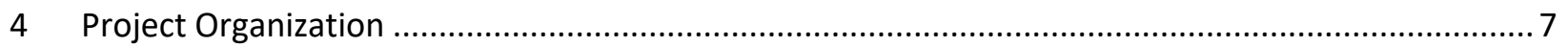

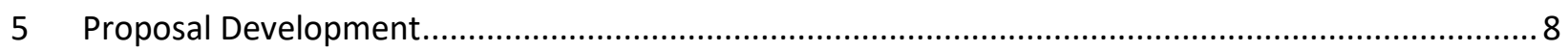

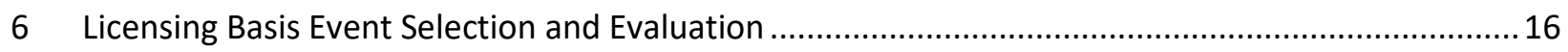

7 Structures, Systems, and Components Classification ................................................................. 18

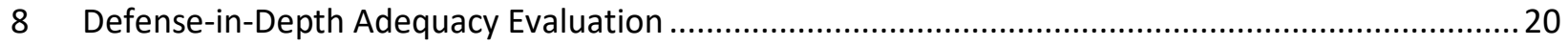

9 Use of Probabilistic Risk Assessment in Licensing Basis Development...........................................22

10 LMP Lessons Learned, Best Practices, and Frequently Asked Questions .......................................24

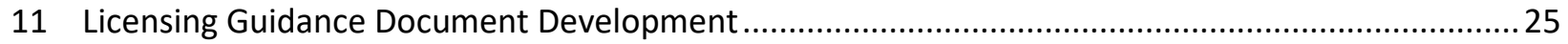

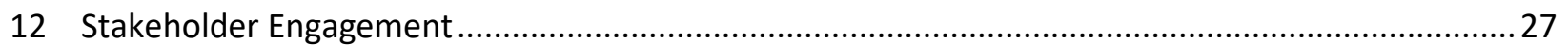

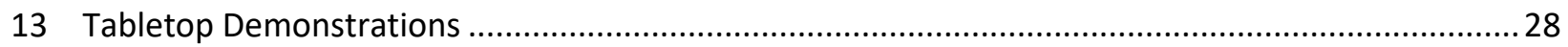

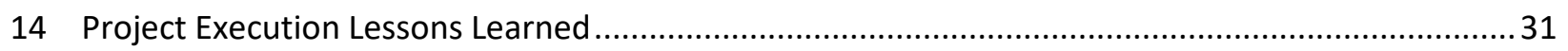

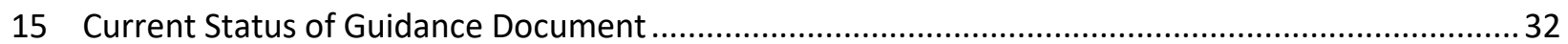

16 Recognition of LMP Contributions to Modernization of NRC Regulatory Framework for

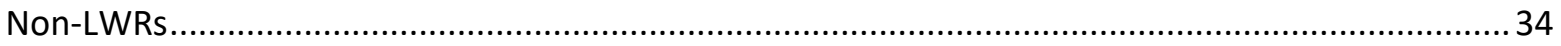

17 NRC Reviews, Drafts, and Actions Leading to NRC Endorsement of LMP Guidance Document .........36

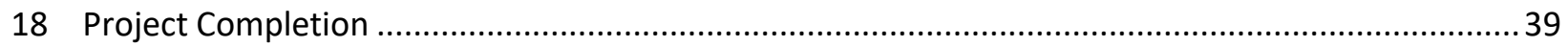

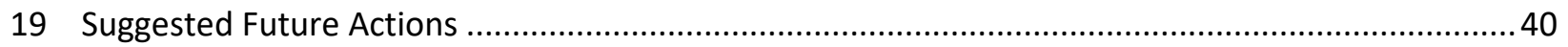

Appendix A-February 6, 2020 Commission Briefing Slides Regarding Licensing Modernization Project (LMP) Delivered by Amir Afzali, Licensing and Policy Director, Southern Company ...........A-1

Appendix B-Speaker's Narrative for February 6, 2020 Commission Briefing Regarding Licensing Modernization Project (LMP) Delivered by Amir Afzali, Licensing and Policy Director, Southern Company 


\section{LIST OF FIGURES AND TABLES}

Figure 1. Primary Elements of the TI-RIPB Licensing Methodology

Table 1. LMP Reports

Table 2. Notable LMP White Paper and Guidance Document Development Records in NRC Agencywide Documents Access Management System (ADAMS).

Table 3. Notable LMP-Specific Development Meetings and Interactions...

Table 4. NRC Regular Meetings with Nuclear Industry Groups and Other Stakeholders on Possible Regulatory Process Improvements for Advanced Reactor Designs Which Included Notable LMP Agenda Items

Table 5. ACRS Meetings Regarding LMP Guidance Document ........................................................... 14

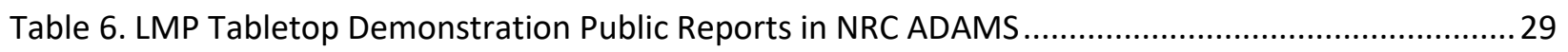

Table 7. NRC-Produced Documents Regarding Endorsement of NEI 18-04 in NRC ADAMS ..................... 37

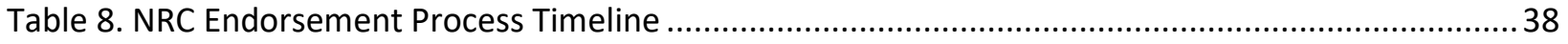




\section{ACRONYMS}

$\begin{array}{ll}\text { ACRS } & \text { Advisory Committee on Reactor Safety } \\ \text { ADAMS } & \text { NRC's Agencywide Document Access Management System } \\ \text { AOO } & \text { Anticipated Operational Occurrence } \\ \text { ARRTF } & \text { NEl's Advanced Reactor Regulatory Task Force } \\ \text { BDBE } & \text { Beyond Design Basis Event } \\ \text { CFR } & \text { Code of Federal Regulation } \\ \text { DBA } & \text { Design Basis Accident } \\ \text { DBE } & \text { Design Basis Event } \\ \text { DID } & \text { defense-in-depth } \\ \text { DOE } & \text { U.S. Department of Energy } \\ \text { DOE-NE } & \text { DOE-Office of Nuclear Energy } \\ \text { FAQ } & \text { frequently asked questions } \\ \text { F-C } & \text { frequency-consequence } \\ \text { FY } & \text { fiscal year } \\ \text { HTGR } & \text { High-Temperature Gas-Cooled Reactor } \\ \text { INL } & \text { Idaho National Laboratory } \\ \text { LBE } & \text { Licensing Basis Event } \\ \text { LMP } & \text { Licensing Modernization Project } \\ \text { LWR } & \text { light water reactor } \\ \text { NEI } & \text { Nuclear Energy Institute } \\ \text { NGNP } & \text { Next Generation Nuclear Plant } \\ \text { non-LWR } & \text { non-light water reactor } \\ \text { NRC } & \text { Nuclear Regulatory Commission } \\ \text { NSRST } & \text { Non-Safety-Related with Special Treatment } \\ \text { NST } & \text { Non-Safety-Related with No Special Treatment } \\ \text { NUREG } & \text { Nuclear Regulatory Report } \\ \text { OSTI } & \text { DOE's Office of Scientific and Technical Information } \\ \text { PB } & \text { performance-based } \\ \text { PRA } & \text { probabilistic risk assessment } \\ \text { RI } & \text { risk-informed } \\ \text { RIPB } & \text { risk-informed and performance-based } \\ \text { SECY } & \text { Commission Papers (from the NRC Office of the Secretary) } \\ \text { SFR } & \text { sodium fast reactor } \\ \text { SR } & \text { Safety-Related } \\ \text { SSCs } & \text { structures, systems, and components } \\ \text { TI } & \text { technology-inclusive } \\ \text { TICAP } & \text { Technology Inclusive Content of Application Project } \\ \text { TI-RIPB } & \text { technology-inclusive, risk-informed, and performance-based } \\ \text { U.S. } & \text { United States } \\ \text { VTR } & \text { DOE's Versatile Test Reactor }\end{array}$




\section{PURPOSE}

Advanced (i.e., non-light-water) reactor technologies offer developers new opportunities to enhance the reliability, efficiency, and safety of nuclear power reactors through changes in fundamental design and operation. A variety of advanced design concepts are being developed that generally trend toward increased reliance on innovative, inherent, and passive safety features. Many of these features are substantially different from components now found in large light water reactors (LWRs) that dominate the commercial operating fleet. Similarly, non-light water reactor (non-LWR) suppliers are also pursuing market niches quite different from the regional baseload power generation sites typically associated with large LWR facilities.

Nuclear plant regulatory safety assessments have focused on LWRs for decades. Consequently, the United States (U.S.) regulatory framework (i.e., regulations, technical requirements, and related compliance guidance) governing nuclear plant design, construction, and operation is tailored to address large LWRs and LWR-derived concepts. This regulatory framework requires updating to be technologyinclusive (TI), with commensurate reductions in associated compliance uncertainties, if non-LWR technologies are to contribute to the domestic energy supply.

The U.S. Nuclear Regulatory Commission (NRC) recognizes that modernization of key elements of the nuclear plant regulatory framework is essential to the commercial success of advanced reactors. Many of these issues appear in the "NRC Vision and Strategy: Safely Achieving Effective and Efficient Non-Light Water Reactor Mission Readiness." ${ }^{1}$ Additional barriers are identified in NRC Vision and Strategy Implementation Action Plans. ${ }^{2,3}$

The Department of Energy (DOE) established the industry-led Licensing Modernization Project (LMP) to update key portions of the NRC regulatory framework and allow advanced reactor deployments to move forward with increased confidence. The scope of this project, executed in conjunction with NRC and industry involvement, specifically targeted assistance to non-LWR design and licensing. The remainder of this report discusses the objectives, activities, and completion of the LMP. 


\section{PROJECT BACKGROUND}

Reactor licensing safety assessments can be divided into a variety of topical groupings that relate to one another based on safety performance and risk. At a fundamental level, these areas are evaluated for acceptability based on radiological dose risks presented to off-site members of the public. DOE chartered the LMP both to examine existing technical regulatory requirements related to the identification, evaluation, and management of advanced reactor accident initiators and sequences and to recommend and implement changes that create a new foundation upon which non-LWR plant safety can be assessed and maintained.

The LMP began this task by systematically reviewing current technical regulatory requirements as they relate to emerging advanced reactor designs and synthesizing an approach adapted to non-LWR paradigms. This approach meets safety performance expectations as currently mandated by existing regulations and provides a means to better demonstrate safety margins. The adaptation was also structured to be accomplished without incurring the long schedule durations typically associated with formal NRC rulemakings; the initial project goal was to provide an adapted and endorsable framework in a timeframe that can be used by non-LWR applicants within 5 years of project initiation.

Project planning started in April 2016 using a small team of subject-matter experts in the areas of commercial licensing and advanced reactor technology. A cost-share arrangement between the DOE Office of Nuclear Energy (DOE-NE) and LMP industry participants, led by Southern Company, established project funding. Additional vendors/suppliers and owners/operators participated in various phases of the project throughout the life of LMP. The LMP team actively solicited this level of stakeholder participation to ensure cross-cutting issues, concerns, and insights were appropriately incorporated into project goals and objectives. At the request of Southern Company, the staff of the Idaho National Laboratory (INL) Regulatory Development Department and the Nuclear Energy Institute (NEI) supplied supplemental technical licensing support throughout the life of the project.

The utility-led LMP structure represents a unique undertaking in regulatory-framework transformation. It is distinctive in that the overall project leadership was provided by a single prospective reactor technology owner-operator (i.e., Southern Company), supported by DOE-NE and DOE labs, and was executed through extensive collaboration with developers, owner-operators, and nuclear regulatory staff.

The project was scoped to build on earlier regulatory framework modernization efforts, leverage the extensive work previously completed, and benefit the entire advanced reactor stakeholder community. This community includes domestic advanced reactor designers and suppliers, utility owner-operators, regulators, and industry advocacy groups. Because project goals were to increase overall framework compatibility for all non-LWR concepts rather than to seek regulatory approval for a single proprietary design, the technology-inclusive nature of the LMP work provided much greater benefit and efficiencies to both regulators and reactor technology developers.

Six classes of advanced reactor technologies were considered in the development of the LMP scope:

- $\quad$ Sodium Fast Reactors (SFRs)

- Lead Fast Reactors

- Gas-Cooled Fast Reactors 
- Modular High-Temperature Gas-Cooled Reactors (HTGRs)

- $\quad$ Fluoride High-Temperature Reactors

- Molten Salt Reactors

The LMP team took deliberate care to ensure that the proposed risk-informed and performance-based (RIPB) framework is technology-inclusive and does not favor or penalize any particular technology. 


\section{PROJECT OBJECTIVES}

As previously discussed, the primary objective of the LMP was to provide high-value, technologyinclusive proposals for facilitating the adaptation of the cross-cutting elements of the regulatory framework in order to meet the underlying safety basis of the current regulation while maximizing licensing efficiency and minimizing unnecessary burden on developers and owner-operators. In addition to identifying and clarifying applicable regulatory requirements, the guidance would also provide for the use of modern, objective, and proven analysis methods for assessing and demonstrating compliance with those requirements.

To achieve the desired enhancements, this guidance would also require formal endorsement by NRC, thereby enabling its use by applicants in future design and licensing decisions. How the LMP met these objectives is described in this report. From the onset of the project, actions that would require rulemaking were excluded from the scope of the project due to the focus on timely, immediately applicable results. However, it was envisioned and purposefully scoped such that its outputs can be used for future rule-making efforts to right-size the regulation for the non-LWR designs where significant innovative approaches to safety improvements can be used to minimize unnecessary burden.

A project engagement strategy supported the LMP action plan. This strategy benefited greatly from the NRC staff's willingness to interact directly with stakeholders to improve the clarity and applicability of agency policies and requirements. Because the agency considers LMP activities "generic," the staff provided support to LMP on an "off-fee" basis.

The transformation approach that emerged from the LMP analysis included the following elements:

- A series of robust, well-justified, related, and clearly actionable proposals (documented in "white papers" which were finally issued as LMP "reports") that included identification of acceptable assessment methods, evaluation criteria, and sources of uncertainty. The proposals were found acceptable to industry and regulatory stakeholders and grounded in suites of proven technical methods amenable to multiple advanced reactor types without incurring extensive modification, adjustment, or interpretation.

- Integrating the various proposals and focusing on the elements of the white papers that should be endorsed by the regulator into a single guidance document, NEI 18-04, "Risk-Informed Performance-Based Technology Inclusive Guidance for Advanced Non-Light Water Reactor Licensing Basis Development," is suitable for NRC review and subsequent endorsement as formal regulatory guidance. The guidance provides an optional pathway for non-LWR applicants to use in implementing their selected regulatory execution plan.

- The prepared guidance increases clarity for developers and NRC reviewers while facilitating full compliance with the underlying safety basis of the established regulatory requirements. Mature and proven assessment techniques and information systematically and objectively identify risk contributors and evaluate consequences for each reactor design as well as providing a clear and integrated picture of the safety margins and defense-in-depth philosophy.

An example of how the new LMP guidance enhances the advanced reactor licensing environment involves NRC regulation 10 Code of Federal Regulations (CFR) 50.34. This regulation requires: 
"... analysis and evaluation ... of the adequacy of structures, systems, and components provided for the prevention of accidents and the mitigation of the consequences of accidents."

Guidance for complying with this requirement is prescribed for LWR applicants. That guidance includes detailed information on what LWR accident scenarios are acceptable for licensing safety review and what constitutes "adequacy" in structures, systems, and components (SSCs) that perform necessary safety functions. Over the years, the LWR owners and operators have adapted and enhanced the guidance to improve its efficiency and usefulness by using more modern analysis methods, including risk-informed, performance-based methodologies, leading to better safety and operational performance. Based on these LWR lessons learned and given the current LWR-centric regulations, safety review accident scenarios are undefined for non-LWR designs and SSC adequacy definitions. The LMP effort was initiated to provide a systematic method for efficiently identifying Licensing Basis Events (LBEs) and objectively classifying SSCs that must reliably function to provide reasonable assurance of adequate protection of the public from the radionuclide release.

As the dominant reactor technology for the past decades has been LWRs, many non-LWR design features that may be relied upon to perform safety function have not yet undergone a complete licensing safety review. Thus, the NRC has not previously prepared the detailed technical guidance that applicants typically rely upon to remove compliance ambiguity. ${ }^{4}$ The LMP recognized the importance of this concern and determined that for licensing uncertainty to be meaningfully reduced, a highlydetailed, technical guidance for methodology usage and adequate training appropriate to the new licensing approach would be needed to aid initial users of the modernized assessment process.

This needed guidance is available in the NEI 18-04 guidance document and the supporting suite of four white papers that provide additional technical and process details to aid advanced non-LWR designers and developers. Training was provided by the LMP team to numerous advanced non-LWR designers in the course of conducting tabletop exercises of the TI-RIPB process on their designs during 2018 and 2019. A TI-RIPB process familiarization session for the NRC staff was held on June 18, 2018, at the NRC Rockville, MD, offices. Additionally, an 8-hour, open training class was held on March 19, 2019, at the NEl offices in Washington, DC.

Details concerning the LMP work scope were summarized in INL's "Regulatory Risk Reduction for Advanced Reactor Technologies-FY 2016 Status and Work Plan Summary." ${ }^{5}$ Subsequent updates to the work plan were described in "Regulatory Risk Reduction for Advance Reactor Technologies: FY 2017 Framework Modernization Proposals and Status" 6 and INL/EXT-18-46151, "Licensing Modernization Project for Advanced Reactor Technologies: FY 2018 Project Status Report, September 2018." 7 These three documents describe the stepwise development of the LMP technical proposals and evaluation methods which are:

- Risk-informed (RI) - The methods provide systematic and robust consideration of the risk to the public during design and licensing.

- Performance-based (PB)-The methods facilitate a clear and (to the extent practicable) direct relationship between advanced reactor performance and the requirements.

- Technology-inclusive (TI)-Proposals and methods have considerations that enable and incentivize innovation across a broad spectrum of advanced reactor concepts. 
While many LMP work activities identified in fiscal year (FY) 2016 and FY 2017 project status reports were modified in response to stakeholder feedback and emergent needs, most adjustments involved simplifications and consolidations of initially planned activities and work products. This project streamlining allowed acceleration of internal project schedules by about one year and moved the LMP products delivery date from 2020 to 2019. 


\section{PROJECT ORGANIZATION}

Organization of the LMP included the following features:

- The project leadership comprised a multi-faceted, utility-led work team (managed by Southern Company) responsible for interactions and discussion with reactor suppliers, owner-operator organizations, and NRC. Southern Company, a leading energy company with decades of experience in LWR operation, is committed to bringing advanced reactor technology to commercial readiness. As a prospective applicant (i.e., an owner-operator) of an advanced reactor design, Southern Company organized and led the LMP industry team to ensure:

a. Opportunity and impact analyses were performed on key regulatory elements and options identified that benefit the advanced reactor community. These opportunities were linked with current NRC requirements, policies, and guidance without creating additional compliance hurdles.

b. Actionable recommendations and proposals were developed and tuned to address major gaps and uncertainties in the regulatory framework related to non-LWRs.

c. The proposals were developed with sufficient detailed and technical adequacy to allow NRC staff to review and issue a Regulatory Guide, with NRC input where necessary, to endorse LMP proposals within a reasonable time frame so that they can be used by the near- and long-term applicants. The guidance is an option that future applicants can choose to utilize when licensing advanced reactor designs.

d. The LMP team included three former NRC commissioners to ensure its proposals were consistent with the long-standing NRC policies, direction, and practices.

- The NEI provided technical interface with representatives of the nuclear industry. NEI is capable in this regard because it regularly represents advanced reactor developers and owner-operators through the Advanced Reactor Regulatory Task Force (ARRTF). The NEI ARRTF charter represents affiliate members before NRC and the public in matters of regulatory concern, thereby offering a single voice for industry when dealing with technical and policy concerns. LMP objectives are critical to the ARRTF, and all LMP proposals were subject to review and feedback by ARRTF members prior to formal release to the DOE or NRC. ${ }^{8}$

- The Regulatory Development Area of the Advanced Reactor Technologies program, managed at INL, provided additional technical input and stakeholder interface support. INL also provided financial support and acted as a project-communication liaison between industry and DOE. 


\section{PROPOSAL DEVELOPMENT}

The LMP team identified four core technical proposals upon which a new TI-RIPB licensing process could be established. Areas of need consisted of (1) details concerning how to systematically and reliably identify LBEs; (2) systematic methods by which physical plant SSCs potentially important to safety can be identified and classified; (3) ways by which defense-in-depth (DID) prevention and mitigation measures can be demonstrated as adequate and acceptable; (4) application of probabilistic risk assessment (PRA) methods that support the new evaluation approach. Furthermore, the LMP team recognized early in the project that these proposals had to be incorporated into a unified assessment approach in order to provide the robustness and consistency needed for both plant design reviews and independent safety assessments. More specifically, the approach had to ensure that:

- The LBEs selected for use in safety assessments adequately cover the range of hazards to which a specific design would be exposed and properly reflect the failure modes appropriate to that design.

- Safety functions are defined in terms of successes and failures of SSCs along the selected LBEs, and they are adequately capable, reliable, diverse, and redundant across layers of defense in the design.

- The safety functions and SSCs have measurable performance criteria for their capabilities and reliabilities to prevent and mitigate accidents with adequate performance monitoring.

- The philosophy of DID is incorporated in both the design and relevant programmatic features. These elements must be included in the license application, along with outcomes of evaluations on DID adequacy.

- Sufficient and integrated design decisions trade off plant capabilities and programmatic capabilities based on risk-informed insights with reasonable assurance of adequate protection.

- The scope and level of detail for plant SSCs and programmatic controls are included and described at levels commensurate with their safety and risk significance.

- Users understand the application of PRA methods that support the new evaluation approach.

- Application of PRA must be capable of addressing first-of-a-kind plants that may consist of two or more reactor modules, as well as non-core sources of radioactive material.

LMP proposal development began in early 2017 in the form of four stand-alone white papers. Highly detailed working drafts of the white papers were written to serve as the basis for subsequent stakeholder reviews and to gather feedback needed to refine the proposals into preliminary regulatory guidance. After initial comments were collected on white paper contents, key information was extracted from the (updated) proposals and consolidated into a single guidance document. Once the guidance document was drafted, further refinements were made as a result of additional iterative reviews by stakeholders. Once those reviews were completed, LMP submitted a complete draft to the NRC for formal agency discussion, Advisory Committee on Reactor Safeguards (ACRS) review, NRC staff preparation of the corresponding draft Regulatory Guide DG-1353 endorsing NEI 18-04, and discussions with the Commissioners.

Project plans and schedules were set to provide for the collaborative engagements needed to refine white paper content and consolidate them into a uniform guidance document. Schedules were set such that white paper reviews would occur in parallel and (somewhat) independently of one another to shorten timelines and more effectively utilize limited project resources.

White-paper development comprised, in chronological order: 
- A technology-inclusive LBE selection and evaluation process;

- A proposal on how existing PRA methods could be used in early design and licensing decisions;

- An approach for classifying plant SSCs with respect to their contribution and importance to safety;

- A quantifiable means by which the adequacy of DID measures could be established, demonstrated, and preserved.

The LMP proposals drew extensively on earlier regulatory white papers generated by DOE's Next Generation Nuclear Plant (NGNP) project. ${ }^{9}$ However, the LMP expanded and updated NGNP information by adding more-recent technical subject matter and incorporating elements that enabled more technology-neutral applications.

All white papers extensively reviewed the history and justifications underlying the use of TI-RIPB criteria in lieu of prescriptive requirements. Specific performance goals were suggested, where appropriate, and regulatory precedents, existing policy decisions, established safety assessment methods, and available evaluation tools were used to the fullest extent possible. A thorough regulatory analysis accompanied each white paper before reviews were conducted, and areas needing updates were highlighted.

From 2016 through 2018, drafts of the white papers were prepared and submitted to industry (via the ARRTF) for technical review and comment. Thereafter, drafts were updated and subsequently transmitted to NRC staff and the industry to support additional industry meetings, public NRC meetings, and feedback. Based on feedback from NRC staff and industry commenters, in March 2018, the LMP team extracted and consolidated the white paper information into a draft guidance document which would later be designated NEI 18-04.

In mid-2019, following continued discussions regarding NEI 18-04 Draft N with industry and the NRC staff, exercising the LMP RIPB methodology with multiple reactor designs and vendors during tabletop exercises of the processes, as well as issuance of a favorable letter from the ACRS, the LMP team performed a final update of the four white papers prior to publication via the DOE's Office of Scientific and Technical Information (OSTI) public document repository. These four white papers were reconciled with NEI 18-04 Rev 1 and issued as independent Revision 0 reports available from the OSTI website (https://www.osti.gov). As described in Section 10 of this report, those reports were later updated in early 2020 to reflect lessons learned from continued execution of the LMP RIPB process by several designers; a new report regarding such lessons learned was also prepared as shown in Table 1. Document citations and details of significant meetings regarding the LMP effort with members of the NRC staff and ACRS are contained in Table 2, Table 3, Table 4, and Table 5. 
Table 1. LMP Reports

\begin{tabular}{|c|c|c|}
\hline Report Title & $\begin{array}{l}\text { Southern Company } \\
\text { Document Number }\end{array}$ & $\begin{array}{l}\text { DOE OSTI } \\
\text { Document Number }\end{array}$ \\
\hline Selection and Evaluation of Licensing Basis Events & SC-29980-100 Rev 1 & TBD \\
\hline Probabilistic Risk Assessment Approach & SC-29980-101 Rev 1 & TBD \\
\hline $\begin{array}{l}\text { Safety Classification and Performance Criteria for Structures, } \\
\text { Systems, and Components }\end{array}$ & SC-29980-102 Rev 1 & TBD \\
\hline $\begin{array}{l}\text { Risk-Informed and Performance-Based Evaluation of } \\
\text { Defense-in-Depth Adequacy }\end{array}$ & SC-29980-103 Rev 1 & TBD \\
\hline $\begin{array}{l}\text { LMP Lessons Learned, Best Practices, and Frequently Asked } \\
\text { Questions }\end{array}$ & SC-29980-106 Rev 0 & TBD \\
\hline
\end{tabular}


Table 2. Notable LMP White Paper and Guidance Document Development Records in NRC

Agencywide Documents Access Management System (ADAMS)

\begin{tabular}{|c|c|c|}
\hline $\begin{array}{l}\text { Document } \\
\text { Date }\end{array}$ & $\begin{array}{l}\text { Associated } \\
\text { ADAMS } \\
\text { Accession } \\
\text { Number }\end{array}$ & Subject \\
\hline 04/30/2017 & ML17104A254 & Draft Licensing Basis Events White Paper \\
\hline 04/30/2017 & ML17145A574 & NRC Staff comments on Draft Licensing Basis Events White Paper; redline, strikeout version \\
\hline $05 / 25 / 2017$ & ML17145A573 & High-level NRC Staff comments on Draft Licensing Basis Events White Paper \\
\hline $05 / 25 / 2017$ & ML17145A570 & Table showing the relationship between analyzed events and other topics and regulations \\
\hline 06/30/2017 & ML17158B543 & Draft Probabilistic Risk Assessment White Paper \\
\hline 08/18/2017 & ML17233A187 & NRC Staff Comments/Questions on Draft Probabilistic Risk Assessment White Paper \\
\hline $10 / 31 / 2017$ & ML17290A463 & Draft Structures, Systems, and Components Classification White Paper \\
\hline $11 / 21 / 2017$ & ML17319A210 & $\begin{array}{l}\text { Preliminary Questions/Comments from NRC staff on Draft Structures, Systems, and Components Classification } \\
\text { White Paper (Comments appear as Enclosure } 3 \text { of Summary of November 2, 2017, meeting.) }\end{array}$ \\
\hline $12 / 12 / 2017$ & ML17354B174 & Draft Defense-in-Depth White Paper \\
\hline $01 / 19 / 2018$ & ML18024A595 & NRC Staff Comments/Questions on Draft Defense-in-Depth White Paper \\
\hline 03/29/2018 & ML18094B085 & LMP Guidance Document Draft H \\
\hline 05/01/2018 & ML18120A321 & Email, NRC staff Comments/Questions on LMP Guidance Document Draft $\mathrm{H}$ \\
\hline $05 / 27 / 2018$ & ML18150A344 & LMP Guidance Document Draft M \\
\hline $09 / 28 / 2018$ & ML18271A172 & LMP Guidance Document NEI 18-04 Draft N \\
\hline $08 / 26 / 2019$ & ML19241A333 & NEI letter to NRC requesting endorsement of NEI 18-04 Rev 1 \\
\hline 08/26/2019 & ML19241A472 & LMP Guidance Document NEI 18-04 Rev 1 \\
\hline
\end{tabular}


Table 3. Notable LMP-Specific Development Meetings and Interactions

\begin{tabular}{|c|c|c|c|}
\hline $\begin{array}{l}\text { Meeting } \\
\text { Date }\end{array}$ & Subject & $\begin{array}{l}\text { Associated ADAMS } \\
\text { Accession Numbers }\end{array}$ & Notes \\
\hline 07/07/2017 & $\begin{array}{l}\text { LMP PRA } \\
\text { approach }\end{array}$ & Not applicable & A drop-in meeting was held with NRC staff to introduce the LMP PRA approach. \\
\hline $11 / 01 / 2017$ & $\begin{array}{l}\text { LMP DID } \\
\text { approach }\end{array}$ & Not applicable & A drop-in meeting was held with NRC staff to introduce the LMP DID approach. \\
\hline $02 / 14 / 2018$ & $\begin{array}{l}\text { LMP/NRC } \\
\text { guidance } \\
\text { document } \\
\text { development }\end{array}$ & $\begin{array}{l}\text { Public Notice ML18029A110; } \\
\text { Meeting Slides ML18054A075; } \\
\text { Meeting Summary ML18054A078 }\end{array}$ & $\begin{array}{l}\text { Discussions explored guidance document format, general technical content, and expected } \\
\text { levels of detail. Potential pathways for NRC endorsement were reviewed and a preferred } \\
\text { pathway identified. }\end{array}$ \\
\hline $\begin{array}{l}04 / 05- \\
06 / 2018\end{array}$ & $\begin{array}{l}\text { LMP/NRC } \\
\text { guidance } \\
\text { document } \\
\text { development }\end{array}$ & $\begin{array}{l}\text { Public Notice ML18073A214; } \\
\text { Meeting Slides ML18109A540; } \\
\text { Meeting Summary ML18113A792 }\end{array}$ & $\begin{array}{l}\text { Review of staff feedback on the consolidation approach was performed for the four LMP } \\
\text { white papers. Discussion continued concerning initial guidance document content. Areas of } \\
\text { technical consensus were identified, and outstanding priority issues such as specific } \\
\text { evaluation criteria (requiring further development) were noted. The meeting reviewed } \\
\text { development schedules and discussed support needs for future process implementation. }\end{array}$ \\
\hline $\begin{array}{l}06 / 05- \\
06 / 2018\end{array}$ & $\begin{array}{l}\text { LMP/NRC } \\
\text { guidance } \\
\text { document } \\
\text { development }\end{array}$ & $\begin{array}{l}\text { Public Notice ML18151A706; } \\
\text { Meeting Summary ML18177A462 }\end{array}$ & $\begin{array}{l}\text { In-depth review of staff comments on the emerging guidance document was conducted. } \\
\text { Potential changes in key F-C curve values were discussed as were attributes of initiating } \\
\text { events and event-sequences. Preparations were made for a briefing to the ACRS } \\
\text { Subcommittee on Future Plant Designs. }\end{array}$ \\
\hline $06 / 18 / 2018$ & $\begin{array}{l}\text { NRC staff } \\
\text { training }\end{array}$ & Not available & $\begin{array}{l}\text { LMP members delivered process familiarization training to NRC staff on the TI-RIPB process } \\
\text { at the NRC White Flint offices. Feedback on the licensing approach was provided by the } \\
\text { attending staff. }\end{array}$ \\
\hline $08 / 21 / 2018$ & $\begin{array}{l}\text { LMP/NRC } \\
\text { guidance } \\
\text { document } \\
\text { development }\end{array}$ & $\begin{array}{l}\text { Public Notice ML18219B470; LMP } \\
\text { Guidance Document Draft M } \\
\text { ML18150A344; Slide Deck } \\
\text { ML18242A447; Meeting } \\
\text { Summary ML18242A396; LMP } \\
\text { Guidance Document Rev N } \\
\text { ML18242A469 }\end{array}$ & $\begin{array}{l}\text { The workshop focused on the development of the LMP draft guidance document and } \\
\text { review of a draft NRC regulatory guide. The agenda included resolution of June NRC and } \\
\text { ACRS comments, glossary clarifications, DBE/DBA considerations, and schedule finalization. }\end{array}$ \\
\hline 03/19/2019 & $\begin{array}{l}\text { LMP industry } \\
\text { training }\end{array}$ & $\mathrm{N} / \mathrm{A}$ & $\begin{array}{l}\text { Training was delivered by LMP team subject matter experts to interested industry } \\
\text { participants at the NEI offices. }\end{array}$ \\
\hline
\end{tabular}


Table 4. NRC Regular Meetings with Nuclear Industry Groups and Other Stakeholders on Possible Regulatory Process Improvements for Advanced Reactor Designs Which Included Notable LMP Agenda Items

\begin{tabular}{|c|c|c|}
\hline $\begin{array}{l}\text { Meeting } \\
\text { Date }\end{array}$ & Associated ADAMS Accession Numbers & Notes \\
\hline $10 / 25 / 2016$ & $\begin{array}{l}\text { Public Notice ML16294A407; Meeting Slides } \\
\text { ML16306A421; Meeting Summary ML16306A416 }\end{array}$ & Introduction of LMP to NRC staff \\
\hline $12 / 15 / 2016$ & $\begin{array}{l}\text { Public Notice ML16335A457; Meeting Slides } \\
\text { ML16355A250; Meeting Summary ML16355A251 }\end{array}$ & $\begin{array}{l}\text { Continued familiarization of the LMP effort with the NRC staff. Notably, the NRC staff } \\
\text { and LMP team agreed that future interactions on the LMP would occur during both the } \\
\text { more generic advanced reactor Stakeholder meetings and LMP-specific meetings. }\end{array}$ \\
\hline $02 / 02 / 2017$ & $\begin{array}{l}\text { Public Notice ML17019A052; Meeting Slides } \\
\text { ML17037D371; Meeting Summary ML17052A809 }\end{array}$ & LMP discussion largely focused on the application of PRA to a RIPB framework \\
\hline $03 / 22 / 2017$ & $\begin{array}{l}\text { Public Notice ML17069A365; Meeting Slides } \\
\text { ML17086A419; Meeting Summary ML17090A574 }\end{array}$ & $\begin{array}{l}\text { LMP discussion on progress to date, questions from the NRC staff regarding PRA, and } \\
\text { plans for white paper submittals }\end{array}$ \\
\hline $\begin{array}{l}05 / 03- \\
04 / 2017\end{array}$ & $\begin{array}{l}\text { Public Notice ML17108A693; Meeting Slides } \\
\text { ML17130A782; Meeting Summary ML17144A403 }\end{array}$ & LMP discussion focused on upcoming LBE and PRA white papers \\
\hline $06 / 22 / 2017$ & $\begin{array}{l}\text { Public Notice ML17163A139; Meeting Slides } \\
\text { ML17177A244; Meeting Summary ML17181A516 }\end{array}$ & LMP discussion focused on NRC staff feedback regarding LBE selection white paper \\
\hline 09/28/2017 & $\begin{array}{l}\text { Public Notice ML17263A067; Meeting Slides } \\
\text { ML17272A141; Meeting Summary ML17319B210 }\end{array}$ & $\begin{array}{l}\text { LMP discussion focused on SSC Classification and was followed by the submittal of the } \\
\text { SSC classification white paper }\end{array}$ \\
\hline $11 / 02 / 2017$ & $\begin{array}{l}\text { Public Notice ML17296B241; Meeting Slides } \\
\text { ML17310B495; Meeting Summary ML17319A210 }\end{array}$ & $\begin{array}{l}\text { LMP discussion focused on NRC staff feedback on the SSC classification white paper and } \\
\text { the forthcoming DID white paper }\end{array}$ \\
\hline $12 / 14 / 2017$ & $\begin{array}{l}\text { Public Notice ML17334A251; Meeting Slides } \\
\text { ML17354B219; Meeting Summary ML18010A447 }\end{array}$ & LMP discussion focused on the DID white paper \\
\hline 02/01/2018 & $\begin{array}{l}\text { Public Notice ML18024A695; Meeting Slides } \\
\text { ML18036A897; Meeting Summary ML18044A038 }\end{array}$ & $\begin{array}{l}\text { LMP discussion focused on NRC staff feedback on the DID white paper, the path } \\
\text { forward to develop the LMP guidance document from the white papers that had been } \\
\text { submitted for review, and plans for the scheduled February 14, 2018, workshop on the } \\
\text { LMP guidance document }\end{array}$ \\
\hline 05/03/2018 & $\begin{array}{l}\text { Public Notice ML18116A248; Meeting Slides } \\
\text { ML18130A688; Meeting Summary ML18131A176 }\end{array}$ & $\begin{array}{l}\text { LMP discussion focused on the draft guidance document and preparations for the } \\
\text { June 19, 2018, ACRS Subcommittee on Future Plant Designs meeting }\end{array}$ \\
\hline 09/13/2018 & $\begin{array}{l}\text { Public Notice ML18249A337; Meeting Slides } \\
\text { ML18264A122; Meeting Summary ML18275A367 }\end{array}$ & $\begin{array}{l}\text { LMP discussion focused on updating NRC staff, the public, and industry on the results of } \\
\text { the June 19, 2018, ACRS Subcommittee on Future Plant Designs meeting, the } \\
\text { August 21, 2018, LMP workshop, and plans for the October 30, 2018, ACRS } \\
\text { Subcommittee on Future Plant Designs meeting }\end{array}$ \\
\hline
\end{tabular}


Table 5. ACRS Meetings Regarding LMP Guidance Document

\begin{tabular}{|c|c|c|}
\hline Meeting Date & $\begin{array}{l}\text { Associated ADAMS } \\
\text { Accession Numbers }\end{array}$ & Subject \\
\hline 06/19/2018 & $\begin{array}{l}\text { Meeting Agenda } \\
\text { ML18162A043; Meeting } \\
\text { Transcript ML18184A148 }\end{array}$ & $\begin{array}{l}\text { LMP introduced the proposed licensing approach to the ACRS Subcommittee on Future Plant } \\
\text { Designs. The agenda emphasized overall process structure and methodology components; } \\
\text { discussions on specific evaluation criteria values remained tentative pending further staff } \\
\text { analysis. Staff offered insights on policy implications of the LMP approach; ACRS } \\
\text { Subcommittee provided initial feedback on Version M of the draft guidance document } \\
\text { (provided to NRC on May 27, 2018). }\end{array}$ \\
\hline $10 / 30 / 2018$ & $\begin{array}{l}\text { Meeting Agenda } \\
\text { ML18297A287; Meeting } \\
\text { Transcript ML18325A049 }\end{array}$ & $\begin{array}{l}\text { The ACRS Subcommittee on Future Plant Designs meeting included NRC staff presentations of } \\
\text { their reviews and feedback on the LMP guidance document NEI 18-04 Draft N, the Staff's } \\
\text { draft of DG-1353, and LMP team presentations on NEI 18-04 Draft N. }\end{array}$ \\
\hline $12 / 05 / 2018$ & $\begin{array}{l}\text { Meeting Agenda } \\
\text { ML18317A358; Meeting } \\
\text { Transcript N/A }\end{array}$ & $\begin{array}{l}\text { LMP topics were on the agenda for the ACRS Full Committee meeting scheduled for } \\
\text { December 5, 2018. This day of ACRS meetings was canceled due to the state funeral of } \\
\text { former President George H. W. Bush in Washington, DC, on the same date. The ACRS Full } \\
\text { Committee meeting topics were re-scheduled for February } 6,2019 .\end{array}$ \\
\hline $02 / 06 / 2019$ & $\begin{array}{l}\text { Meeting Agenda } \\
\text { ML19028A169; Meeting } \\
\text { Transcript ML19105B177; ACRS } \\
\text { Letter Report ML19078A240; } \\
\text { Response from Fred Brown to } \\
\text { ACRS Chair Riccardella } \\
\text { ML19101A292 }\end{array}$ & $\begin{array}{l}\text { The ACRS Full Committee meeting included NRC staff presentations on their reviews and } \\
\text { feedback on the LMP guidance document NEI 18-04 Draft N and on the Staff's draft of DG- } \\
1353 \text { and LMP team presentations on NEI 18-04 Draft N. } \\
\text { The ACRS Full Committee provided their positive response in their letter report on the matter } \\
\text { to Chairman Svinicki dated March 19, } 2019 .\end{array}$ \\
\hline
\end{tabular}


During November and December 2019, the LMP team sought feedback from the advanced reactor designer community on their experiences implementing the LMP process. As a result of this feedback, each of the LMP reports was updated to Revision 1. To capture the valuable cross-cutting lessons learned and best practices identified, and provide consolidated responses to frequently asked questions regarding LMP, such a new report was prepared in March 2020.

Further details about the contents of each completed LMP report are provided in the following sections. 


\section{LICENSING BASIS EVENT SELECTION AND EVALUATION}

The LBE selection and evaluation white paper lists relevant regulatory policies and guidance concerning the identification of LBEs relative to advanced reactor licensing. ${ }^{10}$ The paper proposes a highly detailed technology-inclusive methodology for selecting and classifying LBEs including Anticipated Operational Occurrences (AOOs), Design Basis Events (DBEs), Beyond Design Basis Events (BDBEs), and Design Basis Accidents (DBAs). Other issues important to RIBP licensing evaluations are also noted.

Within the scope of the LMP, the LBE selection and evaluation white paper aimed to:

- Secure NRC agreement on the proposed LBE selection approach for incorporation into an appropriate regulatory guidance document

- Identify issues and topics having the potential to influence the selection and evaluation of advanced reactor LBEs, including AOOs, DBEs, BDBEs, and DBAs

The white paper expands upon information, justifications, and regulatory feedback received from the NGNP LBE selection white paper. ${ }^{11}$ Updates to the legacy NGNP information address technologies other than modular HTGRs in order to make the work broadly technology-inclusive. The LMP LBE selection proposal also modifies the NGNP frequency-consequence (F-C) curve, which is a major consideration in the LBE selection process and a basic evaluation criterion.

The LBE-selection and evaluation white paper also elaborates on how events would be derived using both deterministic and probabilistic elements of risk-informed decision-making. The scope covers the full spectrum of events considered in a safety evaluation. Four major LBE categories, other than daily (normal) operations, are established under the approach:

- Anticipated Operational Occurrences encompass planned and anticipated events. The radiological doses from $\mathrm{AOOs}$ are required to meet normal operational public-dose requirements. AOOs are utilized to set operating limits for normal operation modes and states.

- Design Basis Events contain unplanned off-normal events not expected in the plant's lifetime, but which might occur in the lifetime of a fleet of plants. DBEs are the basis for the design, construction, and operation of SSCs.

- Beyond Design Basis Events are rare off-normal events of lower occurrence frequency than DBEs. BDBEs are evaluated to ensure that they do not pose unacceptable risks to the public.

- Design Basis Accidents for license applications (traditionally found in Chapter 15, "Accident Analyses" in large LWR applications based on Nuclear Regulatory Report [NUREG]-0800) are derived deterministically from DBEs by assuming that only SSCs classified as Safety-Related are available to mitigate consequences. The public consequences of DBAs are based on mechanistic source terms and are conservatively calculated. The conservatively estimated dose of each DBA must meet the 10 CFR 50.34 consequence limit at the Exclusion Area Boundary.

A step-by-step process for selecting LBEs is prescribed in the LMP white paper. The process employs clearly-stated parameters that are systematic, reproducible, sufficiently complete, available for timely input to design decisions, TI-RIBP, and consistent with current and applicable regulatory requirements. Example applications (also known as "tabletops" or "demonstrations") were performed on five historical and proposed reactor designs to demonstrate the LBE selection and evaluation approach to the extent practicable given the design status of the respective candidate reactors. 
The LBE selection and evaluation approach was introduced to NRC staff during a February 2, 2017, public meeting. Concurrent with this introduction, the draft LBE selection and evaluation white paper was reviewed by industry and updated in response to feedback. Another public meeting with the staff was held on March 22, 2017, during which additional details were provided on the overall LMP licensing approach. In April 2017, a working draft of the LBE selection and evaluation proposal was transmitted to NRC staff for initial review. Additional discussions followed during public meetings held on May 3-4, 2017, and June 22, 2017. Staff questions and comments were transmitted to the LMP team in April and May 2017 in the form of high-level written comments, a table showing the relationship among analyzed events and other topics and regulations, and in a redline markup of the white paper.

Other than a project progress update presented to the staff during a November 2, 2017, regulatoryprocess-improvement public-stakeholder meeting, formal response to initial staff feedback was delayed pending completion of LMP proposals dealing with PRA use, SSC classification, and determination of DID adequacy. All proposals were completed in late 2017, and interactions to resolve LBE selection and evaluation comments resumed in January 2018.

Discussions between the NRC staff and the LMP team, including the topic of LBE selection and evaluation, continued at a rapid pace through September 2018. The LMP team met with and received feedback from the ACRS Subcommittee on Future Plant Designs in June and October 2018, and the ACRS Full Committee in February 2019. As the LMP effort progressed, the topics addressed in each of the four white papers were incorporated into iterative revisions of the draft guidance document for review and discussion with the various stakeholders. Document citations and details of significant meetings regarding the LMP effort with members of the NRC staff and ACRS are contained in Table 2, Table 3, Table 4, and Table 5. As noted above, the LBE selection and evaluation white paper was updated in mid2019 for consistency with NEI 18-04 Rev 1 and published in OSTI as report Revision 0, then updated in March 2020 as Revision 1 to incorporate lessons learned. 


\section{STRUCTURES, SYSTEMS, AND COMPONENTS CLASSIFICATION}

The LMP SSC white paper addresses the classification and performance criteria of SSCs potentially important to safety. ${ }^{12}$ The paper identifies technical issues related to the proposed SSC safetyclassification scheme and cites the requirements necessary to support SSC safety-function performance to prevent and mitigate LBEs. Requirements include those that provide a necessary capability to perform a mitigation function and meet reliability requirements that preclude LBEs with more severe consequences.

Within the scope of the LMP, the SSC classification white paper sought to:

- Describe an approach to SSC safety classification compatible with the LMP methodology

- Present a means for determining risk significance and safety significance of SSCS

- Discuss the roles of SSC reliability and capability in the prevention and mitigation of accidents

- Present a top-down process for developing Functional Design Criteria and lower-level design criteria for implementation of required safety functions of SSCs

- Prescribe a process for developing special treatment requirements concerning performance of SSC functions in the prevention and mitigation of LBES

- Reference relevant supporting regulatory guidance, precedents, and available information concerning proposed approach implementation

- Identify key technical issues associated with the proposed approach

- Provide linkage among LMP proposals dealing with PRA development, LBE selection and evaluation, and DID-adequacy evaluation

Safety classification categories were developed from information originally presented in the NGNP white paper on SSC safety classification. ${ }^{13}$ The information was supplemented with additional insights drawn from 10 CFR 50.69 and U.S. and international efforts in this area.

Briefly stated, the LMP proposes an SSC classification basis fashioned around the following categories:

- Safety-Related (SR):

- $\quad$ SSCs selected by the designer to perform required safety functions and mitigate consequences of DBEs to within the LBE F-C evaluation target and to mitigate DBAs that only rely on the SR SSCs to meet the dose limits of 10 CFR 50.34 using conservative assumptions

- SSCs selected by the designer and relied on to perform required safety functions that prevent the frequency of BDBEs with consequences greater than the 10 CFR 50.34 dose limits from increasing into the DBE region and beyond the F-C target

- Non-Safety-Related with Special Treatment (NSRST):

- Non-Safety-Related SSCs relied on to perform risk-significant functions. Risk-significant SSCs are those that perform functions that prevent or mitigate an LBE from exceeding the F-C target or make significant contributions to the cumulative risk metrics selected for evaluating the total risk from all analyzed LBEs

- Non-Safety-Related SSCs relied on to perform functions requiring special treatment for DID adequacy 
- $\quad$ Non-Safety-Related with No Special Treatment (NST):

- All other plant SSCs (with no special treatment required)

Under the proposed approach, safety-significant SSCs include all SSCs classified as SR or NSRST; no NST SSC would be considered safety significant. The TI-RIPB SSC performance and special treatment requirements identified in the document for SR and NSRST SSCs are appropriate to provide reasonable confidence in SSC capabilities and reliabilities consistent with the F-C target and the regulatory dose limits for DBAs.

The LMP introduced the SSC classification concept to NRC staff during a public meeting on September 28, 2017. Concurrent with that meeting, the white paper underwent review by industry and was updated accordingly. In October 2017, a working draft of the updated white paper was transmitted to NRC staff for review. Related staff questions and initial comments concerning the proposal were transmitted back to the LMP in November 2017.

Formal response to staff feedback was delayed pending completion of the remaining white paper on determining DID adequacy. The DID proposal was completed in December 2017, and responses to SSCclassification comments were developed in conjunction with the January 2018 initiation of guidance document development.

Discussions between the NRC staff and the LMP team, including several on the topic of SSC classification, continued at a rapid pace through September 2018. The LMP team met with and received feedback from the ACRS Future Designs Subcommittee in June and October 2018 and the ACRS Full Committee in February 2019. As the LMP effort progressed, the topics addressed in each of the four white papers were incorporated into iterative revisions of the draft guidance document for review and discussion with the various stakeholders. Document citations and dates for significant meetings regarding the LMP effort with members of the NRC staff and ACRS are contained in Table 2, Table 3, Table 4, and Table 5. As noted above, the SSC classification white paper was updated in mid-2019 for consistency with NEI 18-04 Rev 1 and published in OSTI as report Revision 0, then updated in March 2020 as Revision 1 to incorporate lessons learned. 


\section{DEFENSE-IN-DEPTH ADEQUACY EVALUATION}

Defense-in-depth is a longstanding safety philosophy applied to all nuclear plant designs. However, definitive regulatory guidance for evaluating and confirming the adequacy of DID mitigations is lacking. To address this source of uncertainty, the LMP developed a DID adequacy evaluation approach consistent with historical philosophies, NRC policies, and insights from NUREG/KM-0009, "Historical Review and Observations of Defense-in-Depth," ${ }^{14}$ and related industry standards like IAEA's Safety Report Series No. 46, "Assessment of Defense in Depth for Nuclear Power Plants." 15

The LMP white paper describing DID adequacy evaluations examines the purpose, history, and policies related to DID and identifies applications available for use at nuclear reactor facilities. ${ }^{16}$ Within the context of the LMP, specific objectives of the white paper included:

- Establishing alignment with DID philosophy definitions and describing how multiple layers of defense can be deployed to confirm DID adequacy

- Describing how protective DID strategies are used to define the DID attributes incorporated into plant capabilities that support each layer of defense. The resolution of general protective strategy concepts into sets of DID attributes is necessary to support the objective evaluation of DID adequacy. These DID attributes are reflected in plant design features, reliabilities, and capabilities of SSCs that include fission-product barriers contributing multiple, functionally independent layers of defense in the prevention and mitigation of accidents.

- Summarizing programmatic attributes of DID to provide assurances that DID plant design capabilities are realized during the entire plant design lifecycle

- Discussing the role of programmatic DID attributes to compensate for uncertainties, human errors, and hardware failures

- Identifying the importance of defense against common-cause failures and the need to minimize dependencies among layers of defense

- Presenting guidelines for evaluating and establishing a DID adequacy baseline

- Providing agreement on how DID adequacy can be achieved among those responsible for designing, operating, reviewing, and licensing advanced non-LWRs

Using LBE scenarios and SSC-classification proposals, in conjunction with RIBP definitions, as a frame of reference, the LMP developed a set of DID practices for use in different types of safety decision-making. A technical basis for DID adequacy is presented along with strategies for TI-RIPB improvements achieved through design, safety capabilities, and programmatic controls. When implemented, the proposed DID approach should provide a more objective means to answer the important question for a specific design regarding DID: When is enough, enough?

The LMP proposal is crafted to assure adequate and consistent application of DID measures with respect to public protection from radiological exposure due to accidental release. Additionally, the robust nature of the approach is expected to benefit other types of DID adequacy determinations (i.e., industrial safety) beyond those associated with radiological protection.

An introduction to the DID approach was delivered to the NRC staff during a November 1, 2017, drop-in meeting. Concurrent with that meeting, industry representatives reviewed and provided comments on the content of the draft white paper. The DID adequacy determination approach was then presented to the staff during a public meeting on December 14, 2017. A draft version of the white paper was 
transmitted to the staff at that time. Staff questions and comments relating to the proposal were received in January 2018.

LMP responses to DID feedback were merged with other pending responses for prior white papers. A follow-up interaction on DID adequacy, along with an overall LMP status update, was provided to the NRC staff during a February 1, 2018, public stakeholder meeting.

Discussions between the NRC staff and the LMP team, including the topic of DID adequacy, continued at a rapid pace through September 2018. The LMP team met with and received feedback from the ACRS Future Designs Subcommittee in June and October 2018, and the Full ACRS Committee in February 2019. As the LMP effort progressed, the topics addressed in each of the four white papers were incorporated into iterative revisions of the draft guidance document for review and discussion with the various stakeholders. Document citations and dates for significant meetings regarding the LMP effort with members of the NRC staff and ACRS are contained in Table 2, Table 3, Table 4, and Table 5. As noted above, the DID adequacy white paper was updated in mid-2019 for consistency with NEI 18-04 Rev 1 and published in OSTI as report Revision 0, then updated in March 2020 as Revision 1 to incorporate lessons learned. 


\section{USE OF PROBABILISTIC RISK ASSESSMENT IN LICENSING BASIS DEVELOPMENT}

The TI-RIPB assessment process relies on well-established PRA methodologies. The technique can be used both in plant design and to support licensing decisions. Furthermore, PRAs can be applied early in design development and continue to be used through design maturation and the operational life of the plant. Precisely how PRAs are employed in this capacity is the subject of an LMP white paper. ${ }^{17}$

Within the scope of the LMP, the objectives of the LMP PRA white paper were to:

- Identify similarities and differences between the LMP approach to using PRA and the approach that has been used in LWR applications;

- Identify key technical issues that must be resolved for successful application of PRAs to advanced non-LWRs;

- Describe an approach that uses available guides, standards, and peer-review processes to assure technical adequacy of the PRA;

- Define a means to develop the PRA so it can be used to provide necessary inputs to the selection of LBEs, as well as provide information that aids in the safety classification of SSCs, the formulation of special-treatment requirements, and performance of risk-informed evaluations of defense in depth;

- Describe an approach to PRA treatment of integrated risk from the operation of a multi-module reactor plant.

The technical approach and applications presented in the white paper enable PRAs to serve as an essential support mechanism for the licensing framework because they facilitate:

- Evaluations of design alternatives that clearly incorporate risk insights into the design;

- New probabilistic inputs to the definition of a safety function associated with SSCs in the prevention and mitigation of initiating events and event sequences;

- Probabilistic inputs to the selection of LBEs;

- Probabilistic input to the selection of SR SSCs;

- Inputs to the definition of special-treatment and design requirements regarding performance, capability, and reliability of additional SSCs used in the prevention and mitigation of initiating events and event sequences;

- The basis for risk-informed evaluation of DID.

The use of PRA in licensing is expected to be far-ranging and to emphasize the systematic application of probabilistic insights. The PRA white paper also offers recommendations to avoid delays in addressing external hazards, embraces the full quantification of associated uncertainties, and heeds lessons learned from the Fukushima Daiichi accident.

The concept of using PRA techniques in advanced reactor licensing was introduced to NRC staff during a public meeting held on May 4, 2017. Concurrently, the white paper was reviewed by industry and updated. A working draft of the PRA white paper was transmitted to NRC staff in June 2017, for initial review and feedback. Additional discussions about PRA use occurred during a public meeting held at NRC headquarters on June 22, 2017, and during a drop-in meeting on July 7, 2017. Related staff questions and comments concerning PRA use were communicated to the LMP in August 2017. 
A public meeting was held to discuss questions received from the staff on September 28, 2017, but detailed responses were postponed pending completion of SSC classification and the determination of DID adequacy proposals. Proposals were completed in late 2017, and the formal response to the NRC staff's PRA white paper comments began in January 2018 in connection with guidance document development.

Discussions between the NRC staff and the LMP team, including the topic of PRA use in non-LWR licensing actions, continued at a rapid pace through September 2018. The LMP team met with and received feedback from the ACRS Future Designs Subcommittee in June and October 2018, and the ACRS Full Committee in February 2019. As the LMP effort progressed, the topics addressed in each of the four white papers were incorporated into iterative revisions of the draft guidance document for review and discussion with the various stakeholders. Document citations and dates for significant meetings regarding the LMP effort with members of the NRC staff and ACRS are contained in Table 2, Table 3, Table 4, and Table 5. As noted above, the PRA white paper was updated in mid-2019 for consistency with NEI 18-04 Rev 1 and published in OSTI as report Revision 0, then updated in March 2020 as Revision 1 to incorporate lessons learned.

Although, as of this revision of this report, NRC has not yet endorsed the PRA standard for advanced non-LWRs ${ }^{18}$ and the peer review process has not been fully updated to reflect this standard, the staff is currently performing a review of that standard and its revision to be published in 2020 and plans to publish a regulatory guide that endorses the 2020 version similar to RG 1.200 when this review is completed. ${ }^{19}$ 


\section{LMP LESSONS LEARNED, BEST PRACTICES, AND FREQUENTLY ASKED QUESTIONS}

During November and December 2019, the LMP team sought feedback from the advanced reactor designer community on their experiences implementing the LMP process over the preceding months. Each of the five reactor facility designers that participated in the 2018 and 2019 LMP tabletop exercises were interviewed by phone or during a site visit. Additionally, the entire advanced reactor designer community was invited to provide feedback during the December 11, 2019, meeting of the NEI Advanced Reactor Regulatory Task Force.

To address material that is common to multiple LMP reports, a new LMP report was prepared in early 2020 titled "LMP Lessons Learned, Best Practices, and Frequently Asked Questions." This new report includes collected lessons learned, best practices, and frequently asked questions (FAQ) with corresponding LMP team responses. This new report is identified in Table 1, for easy, enduring reference for future users of the LMP methodology.

An LMP team member prepared a list of questions to use as conversation starters with the advanced reactor designers based on previous verbal and written feedback to the LMP team, updated as the effort continued. Interviews were then conducted in-person or over the phone with five advanced reactor designers. Actionable feedback (questions, suggestions, lessons learned, etc.) from all designer meeting notes were then sorted into five spreadsheets corresponding to the existing four LMP reports topics (Probabilistic Risk Assessment; Licensing Basis Events; Structures, Systems, and Components Classification; Defense-in-Depth Adequacy) and a new spreadsheet for common, cross-cutting feedback. The feedback as added to the spreadsheets was essentially verbatim from the meeting notes and contained designer-identifying information in context.

Once assembled, the LMP team reviewed the feedback spreadsheets. The LMP team found that while there were some unique topics raised by individual designers, the feedback received across multiple interviews was often regarding the same topics. From the 79 individual line items (most consisting of multiple related thoughts, questions, and suggestions), the LMP team prepared 32 FAQ which captured the underlying issues of the collected feedback, grouped according to LMP report topics. This process allowed the LMP team to maintain the anonymity of the commenters while presenting the topics in a more technology-inclusive manner to the designer community.

The LMP team then prepared responses to each of those $32 \mathrm{FAQ}$. These answers provide additional background, context, explanation, and references for the FAQ. In some instances, cross-references between $F A Q$ are included.

Each of the existing LMP reports was updated to include a new attachment containing the list of FAQs with a pointer for the reader to the new LMP report addressing the FAQ. The new LMP report includes all the $F A Q$ and responses.

In addition to questions from the designer community, the participating reactor designers provided the LMP team a wealth of information regarding best practices and lessons learned from implementing the LMP RIPB process. As with any new process, especially one that represents a radical shift from past practices in roles and tasks throughout the reactor design and licensing community, both technical and administrative challenges were encountered by early adopters. This feedback is provided to future users of the LMP RIPB process in the new report as an aid for thoughtfully and efficiently planning and implementing the LMP process. 


\section{LICENSING GUIDANCE DOCUMENT DEVELOPMENT}

The most significant project deliverable is the regulatory guidance document, NEI 18-04 "Risk-Informed Performance-Based Technology-Inclusive Guidance for Non-Light Water Reactor Licensing Basis Development." The licensing guidance document summarizes the foundational TI-RIPB concepts and guides the user through the implementation of the methodology for developing the licensing basis of a given non-LWR design. With the DOE, LMP team, and NRC working in cooperation within their respective roles, the desired outcome is NRC endorsement of NEI 18-04 via issuance of a new Regulatory Guide. NEI 18-04 Rev 0 was provided to INL on April 3, 2019, satisfying completion of that INL contract deliverable. NEI 18-04 Rev 1 was transmitted to the NRC on August 26, 2019. As of the submittal date of this report, the NRC is in the process of obtaining formal Commission approval of the Staff-proposed draft Regulatory Guide DG-1353 via a Staff Requirements Memo, to be followed by the issuance of the proposed Regulatory Guide endorsing NEI 18-04.

The release of the draft DID white paper marked the conclusion of the initial LMP proposal development. Beginning in January 2018, the project shifted emphasis to the development of a guidance document. Guidance development started by extracting key technical requirements and other information suitable for inclusion in a regulatory guide from the white papers and adjusting content and format. LMP began compiling and editing the guidance document in January 2018 with an annotated outline of the expected work product. The outline focused on capturing topics related to the identification, quantification, and management of sources of design and operational risk to the public, as those were the topics for which the LMP was seeking formal NRC endorsement. Extensive subjectmatter discussions like process development histories and justification details on methodologies were avoided since those implementation specifics are reflected in detail in the four associated white papers which are intended for use by reactor designers and developers and are below the level of needed NRC endorsement.

The contextual relationship of the LMP approach and licensing basis as presented in the guidance document is shown in Figure 1.

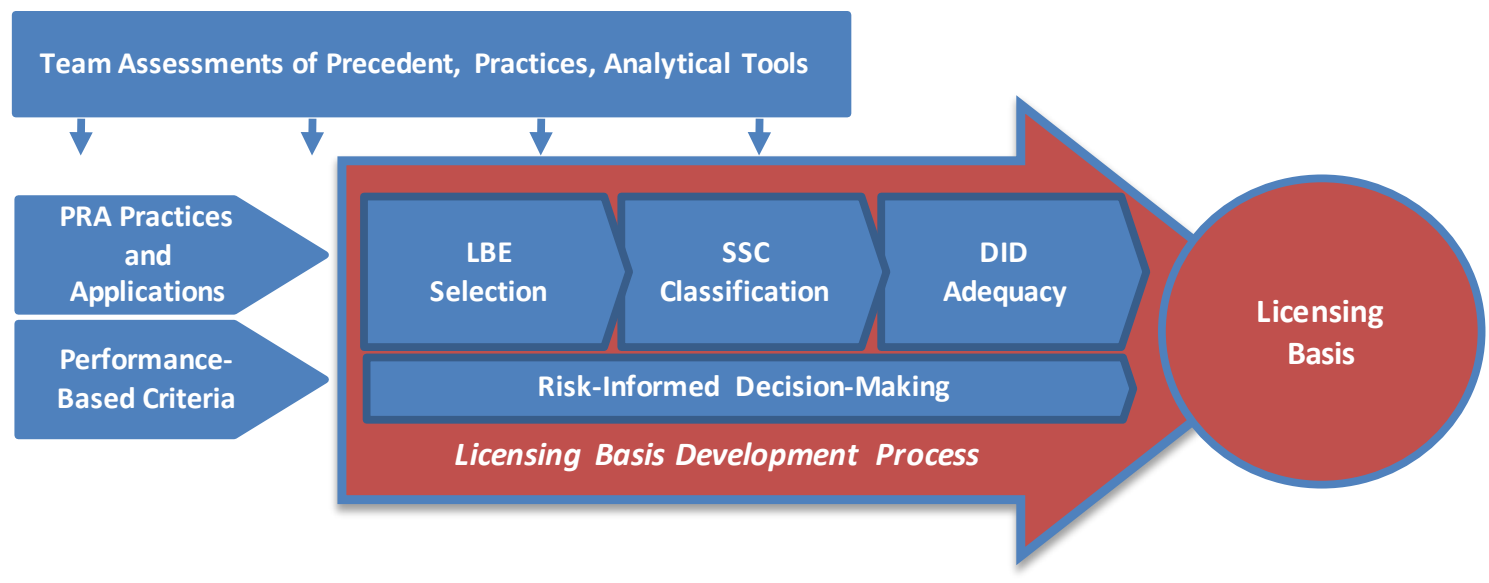

Figure 1. Primary Elements of the TI-RIPB Licensing Methodology

The document provides licensing-basis guidance by integrating LMP-proposed methodologies to present: 
- Clarity on how established risk-analysis techniques (i.e., PRA) can be acceptably used as part of risk-informed decision-making both early in and continuing through plant design life cycles;

- A versatile and generic process for selecting risk-informed, performance-based LBEs;

- A method by which plant SSCs can be systematically evaluated, classified, and assessed with respect to their contribution to safety;

- Defined objectives and reproducible means by which the adequacy of DID safety measures can be established and preserved throughout the entire plant design and operational life cycles.

The LMP work shifted away from initial proposal development to guidance document generation in early 2018. Even as the focus of the work shifted to the guidance document, all parties remained committed to a reconciliation of the completed guidance document and the four white papers once the guidance document had been scrutinized by the ACRS and members of the public. This update of the four white papers to reflect final guidance document content was an important project work activity because these documents are expected to provide users with additional background information, supplemental technical-basis material, and operational advice needed to implement the approach contained in the guidance document. Notably, the LMP team, NRC, and DOE agreed that the white papers are at the level of detailed industry implementation guidance and thus were not submitted for NRC review or endorsement. The white paper update work was completed in the Summer of 2019 with the issuance of Revision 0 of the four LMP reports listed in Table 1. As noted in Section 10 of this report, further updates to these reports were performed in early 2020 to incorporate designer implementation experience. 


\section{STAKEHOLDER ENGAGEMENT}

Working meetings to bring guidance document content to maturity occurred frequently throughout 2018 with additional meetings in 2019 among stakeholders to address feedback regarding NEI 18-04 and discuss the NRC staff DG-1353 and related Commission Papers (SECY) during their public comment periods. Essential participants in this effort included LMP, NEI (including reactor designers and project developers via the ARRTF), and NRC staff tasked with refining LMP proposals and confirming which TI-RIPB material (extracted from the white papers) merited inclusion in the guidance document which would be reviewed and endorsed by the NRC.

Industry reviews of the guidance document were facilitated through the ARRTF. Some ARRTF members are now actively developing licensing applications for their proprietary designs; thus, their input was an important component in the LMP process.

Face-to-face working meetings were the primary means by which stakeholder participants communicated their feedback and established an initial consensus. All meetings were open to public participation and supplemented by informal drop-in meetings, teleconferences, and emails when necessary to support progress. Table 3 lists the LMP-specific primary work meetings between the LMP team, DOE, and NRC that significantly contributed to guidance document development. Notable routine NRC public stakeholder meetings and ACRS interactions follow in separate tables.

Another important source of feedback came from periodic NRC public-stakeholder meetings on advanced reactor process improvement. These regularly scheduled meetings, sponsored and conducted by NRC staff, focused on regulatory-process improvement opportunities specific to advanced reactor designs. More information on these meetings, including meeting slides and summaries, can be found on the NRC website at https://www.nrc.gov/reactors/new-reactors/advanced.html\#stakeholder. Table 4 identifies NRC public stakeholder meetings with significant LMP content. Typically, the ARRTF would meet the day before a scheduled NRC Stakeholder meeting to discuss the agenda topics, including LMP agenda items. 


\section{TABLETOP DEMONSTRATIONS}

As LMP white paper proposals underwent development, prospective licensing approach users within industry (along with NRC staff) expressed interest in modeling important process elements against actual proprietary designs. Such demonstrations were not explicitly incorporated into the original LMP work scope and were not considered essential to guidance document development or obtaining NRC endorsement. However, the performance of tabletop exercises was viewed as an opportunity to collect supplemental insights about overall approach implementation and increase prospective user familiarity with the emerging process. Furthermore, demonstrating process applications against contemporary non-LWR safety approaches would also serve to increase stakeholder confidence in the technologyinclusive attributes of the new licensing approach and likely accelerating deployment timeframes and efficiencies.

From early 2018 to mid-2019, the LMP supported industry demonstrations of the advanced reactor licensing process. These exercises were independent of one another and performed in the context of a proprietary reactor design currently under development for the commercial energy market.

Developers who sponsored an LMP licensing exercise evaluation of their design process in cooperation with the LMP team were required to:

- Provide resources and support that adequately enables preparation for and performance of an LMP tabletop level exercise;

- Provide design data and information for their concept appropriate to the exercise scope and test parameters; these data must allow for a public discussion during exercise work meetings;

- Allow publication of a work-products summary that captures exercise findings and conclusions; this summary would be shared with ARRTF and NRC staff.

Findings and observations resulting from these demonstrations were reviewed by the LMP team, and often by NRC staff at the discretion of the reactor designer, and provided a basis for revisions to the guidance document, finalized white papers, or both.

Five tabletop demonstrations were performed in cooperation with the LMP team: (1) the X-energy pebble-bed HTGR, (2) the GE-Hitachi integral SFR, (3) the Kairos TRISO-fueled, molten salt cooled reactor, (4) the 1965 Oak Ridge National Laboratory Molten Salt Reactor Experiment as investigated by the Electric Power Research Institute/Vanderbilt University, and (5) the Westinghouse eVinci solid-state heat pipe reactor. Each organization has submitted their tabletop reports to the NRC for information; corresponding NRC ADAMS numbers appear in Table 6. 
Table 6. LMP Tabletop Demonstration Public Reports in NRC ADAMS

\begin{tabular}{cll}
\hline $\begin{array}{c}\text { Document } \\
\text { Date }\end{array}$ & $\begin{array}{c}\text { Associated } \\
\text { ADAMS Accession } \\
\text { Number }\end{array}$ & \\
\hline 08/18/2018 & ML18228A779 & $\begin{array}{l}\text { X-energy High Temperature Gas Reactor LMP tabletop } \\
\text { demonstration public report }\end{array}$ \\
12/31/2018 & ML19036A584 & $\begin{array}{l}\text { General Electric-Hitachi PRISM Sodium Fast Reactor LMP tabletop } \\
\text { demonstration public report }\end{array}$ \\
$08 / 12 / 2019$ & ML19227A322 & $\begin{array}{l}\text { Westinghouse eVinci Micro Reactor LMP tabletop demonstration } \\
\text { public report }\end{array}$ \\
09/03/2019 & ML19247C198 & $\begin{array}{l}\text { Kairos Power LMP tabletop demonstration public report } \\
\text { EPRI Molten Salt Reactor Experiment (MSRE) LMP tabletop } \\
\text { demonstration public report }\end{array}$ \\
\hline
\end{tabular}

Independent of LMP team participation, metallic-fueled microreactor developer Oklo performed an exercise and submitted a report titled "DG-1353 Pilot"20,21 to the NRC in the Fall of 2018. Oklo's report is not included in the above accounting of LMP-coordinated demonstration exercises.

In addition to these tabletop exercises, the DOE Versatile Test Reactor (VTR) project has elected to adapt and use the LMP proposals for developing the safety basis for the DOE authorization. The VTR is based on the General Electric-Hitachi PRISM sodium fast reactor; numerous key contributors to the VTR project participated in the PRISM LMP tabletop demonstration to gain experience and distribute LMP familiarity across the VTR organization.

Ultimately, each of these tabletop exercises concluded that the proposed RIPB process was workable and applicable to the particular reactor technology and offered material benefits to the designer if implemented successfully in an actual application. The LMP team worked diligently to incorporate the lessons learned from the exercises into the NEI 18-04 guidance document and associated final white papers. Key insights from these tabletops are listed below.

- The LMP-proposed RIPB framework is not yet familiar to many developers. Decades of prescriptive regulations and deterministic analyses have entrenched such practices as expected "business as usual" within the industry. Implementing RIPB design and licensing will take extensive socialization, familiarization, training, and commitment effort throughout the designer organization to be effective. On the other hand, the experience with the LWR design and licensing and its impact on operational efficiency as well as the implementation of many incremental RIPB programs by the current operating fleet indicate that there are significant safety and operational flexibility improvements that can be gained through the use of RIPB programs.

- The PRA scope should be tightly defined, especially in the conceptual stage of design, to prevent excessive analytical effort. Thus, a common understanding of "fit for purpose" should be shared among the PRA analysts, designers, and the regulatory team.

- Calculation of radiological consequences will be challenging for those reactor technologies with relatively low states of knowledge regarding involved radionuclides, transport mechanisms, and 
layers of defense against such releases. Treatment of uncertainties will be key and are expected to receive keen regulatory scrutiny.

- For those developers that choose to use the process during design development (versus as a tool to demonstrate that their designs meet the underlying safety basis of the regulation), the iterative nature of the RIPB process must be well communicated and understood by all design team members. The application of RIPB methods is part of the ongoing effort throughout design and licensing, extending to the development of operational programs and performance monitoring, rather than a one-time event at the conclusion of the design process. NEI 18-04 is not intended to prescribe how the proposed processes should be incorporated into the design development framework of a particular developer. However, incorporation in the early stages of design development is highly encouraged to allow developers to gain the maximum benefit from the process. 


\section{PROJECT EXECUTION LESSONS LEARNED}

The accomplishment of the LMP resulted in three major lessons learned. First and foremost, rapid advances in the state of practice of the U.S. nuclear power regulatory framework are possible with aligned stakeholders. While the proposed TI-RIPB methodology has not yet received formal NRC endorsement, the cooperative action of the DOE, industry members, and the NRC facilitated both the speed and quality of the LMP proposed methodology. Building on prior work and relationships was fruitful.

Second, there are significant differences in the regulatory compliance plans and the needs of different reactor developers due to variations in the technology and designs within each technology. Developing the same level of regulatory prescriptive requirements and guidance as that which has been developed over 40 years for the legacy operating LWR fleet would take many years and would not facilitate the timely deployment of innovative solutions.

Third, the regular, incremental meetings among the LMP team, industry, and NRC staff were critical in developing a timely and high-quality endorsable guidance document. This engagement assisted all parties in staying informed and engaged as the LMP documents were developed. As a result, key concerns were raised and addressed at opportune times. 


\section{CURRENT STATUS OF GUIDANCE DOCUMENT}

NEI 18-04 Rev $0^{22}$ was issued by the NEI to the DOE on April 3, 2019. This revision is a full and complete document, issued by NEI for use by industry. After consultation and with the concurrence of the NRC staff, NEI 18-04 Rev 0 was not provided to the NRC for endorsement to maintain an internally consistent review of NEI 18-04 Draft N and DG-1353 across the agency and members of the public through the DG-1353 public comment period, which closed July 2, 2019.

NEI 18-04 Rev 1 was developed in mid-2019 and incorporated feedback from industry users and NRC staff, as well as minor editorial changes. A review of the changes by LMP team members concluded that no changes to intent or meaning were made in the edits with respect to Rev 0. On August 26, 2019, NEI transmitted a letter ${ }^{23}$ to the NRC requesting NRC endorsement of NEI 18-04 Rev $1 .{ }^{24}$

At this time, the LMP licensing safety-analysis approach is firmly established and not expected to change substantially during forthcoming regulatory reviews or the NRC endorsement process. However, individual assessment criterion values may be adjusted from values proposed by the LMP as a consequence of comments received from NRC. The LMP is expected to continue collaboration with NRC and other stakeholders through NRC endorsement and incorporate feedback that assures appropriate consensus is maintained.

NRC endorsement of the proposed licensing approach, i.e., NEI 18-04, is necessary if the primary project objective-establishing a more effective means of satisfying applicable regulations for non-LWRs that is acceptable to the NRC-is to be achieved. Key considerations regarding the NRC endorsement of NEI 18-04 include:

- The guidance document provides a stand-alone foundation for a new TI-RIPB licensing approach. It specifies the technical methods and requirements proposed for use by both industry and regulators. No additional documents will require regulatory approval prior to using the approach. While external documents are cited in the guidance document, these citations are meant to provide history, context, and information on specific tasks, as well as pointers to existing and applicable requirements and guidance.

- The TI-RIPB techniques contained in the guidance document are based on information and methods derived from well-established research and testing activities stretching back decades and continuing to the present. No additional research and development of the methodology is necessary prior to NRC endorsement. While the methods may be new for use in a licensing action, the techniques, and methods themselves are proven and not experimental.

- Supplemental guidance that supports the use of the LMP licensing approach may be needed in the future. This includes developing operational details about TI-RIPB process implementation as well as how the process relates to other elements of the still-evolving advanced reactor regulatory framework. Development of supplemental regulatory guidance is not currently in the LMP scope; subsequent collaborative efforts would be needed to develop such guidance.

- The LMP framework modernization approach did not incur a rulemaking action. Such rulemaking typically requires substantial schedule and resource commitments that were not in the near-term interest of the advanced reactor community. Immediate implementation of the LMP licensing approach presumes that appropriate exemptions or departures from current regulations and requirements will adequately facilitate process deployment and use. Should it 
later be determined that rule promulgation is required, the NRC will be responsible for initiating such action.

NRC is the lead agency responsible for scheduling and implementing agency requirements, policies, and practices leading to regulatory guidance endorsement.

In December 2019, the NRC Staff proposed endorsement of NEI 18-04 in their SECY-19-0117

"Technology-Inclusive, Risk-Informed, and Performance-Based Methodology to Inform the Licensing Basis and Content of Applications for Licenses, Certifications, and Approvals for Non-Light-Water Reactors" to the Commissioners requesting Commission approval of the use of the TI-RIPB LMP methodology via Notation Vote.

On February 6, 2020, Southern Company Next Generation Licensing and Policy Director Amir Afzali spoke to the full Commission ${ }^{25}$ and answered questions on LMP; his presentation and speaker's notes are attached to this report as Appendix $A$ and Appendix B, respectively. At the same Commissioners meeting, both Alice Caponiti, Deputy Assistant Secretary, Office of Nuclear Fleet and Advanced Reactor Development, U.S. Department of Energy and John Segala, Branch Chief, Advanced Reactor Policy Branch, Division of Advanced Reactors and Non-Power Production and Utilization Facilities, Office of Nuclear Reactor Regulation, spoke in full support of the LMP RIPB methodology and expectations for future use.

As of the date of this report, the Commissioners' formal votes on SECY-19-0117 remain outstanding. The present expectation is that NEI 18-04 Rev 1 will be cited by the NRC staff's proposed Regulatory Guide as the endorsed version. NEI 18-04 Rev 1 will be subject to ACRS review in the course of their routine review of the associated proposed Regulatory Guide. These forward-looking plans are, of course, subject to change. 


\section{RECOGNITION OF LMP CONTRIBUTIONS TO MODERNIZATION OF NRC REGULATORY FRAMEWORK FOR NON-LWRS}

It is worth noting that the value of the LMP effort has been recognized as an important step in improving timely and efficient advanced reactors reviews while continuing to protect public health, safety, and security. For example, on February 20, 2018, three former NRC commissioners (i.e., Hon. George Apostolakis, Hon. Jeffrey S. Merrifield, and Hon. Richard A. Meserve, each serving in an advisory capacity to the LMP) sent a project assessment letter to Mr. Stephen Kuczynski, Chairman, President, and Chief Executive Officer of Southern Nuclear Operating Company. In it, the authors "enthusiastically endorsed the effort" and expressed their belief that the project, focused on systematically and predictably establishing a process for early resolution of fundamental technical issues, can indeed reduce uncertainty in the development of a new design. The letter further acknowledged that the project actively addresses gaps in several foundational areas where current regulations and guidance are either silent or inadequate for non-LWR designs. These former commissioners, having met with numerous stakeholders regarding the LMP (including individuals at NRC), encouraged the continuation of this beneficial work.

Similarly, on February 21, 2018, Mr. Frederick Brown, Director of NRC Office of New Reactors, transmitted a letter ${ }^{26}$ to Mr. Stephen Kuczynski, Chairman, President, and Chief Executive Officer of Southern Nuclear Operating Company, acknowledging the useful interactions between LMP and NRC staff. The communication also underscored the importance of the LMP effort in helping set the stage for the development of more formal guidance.

A response ${ }^{27}$ to Mr. Brown's letter was sent on March 9, 2018, from Mr. Kuczynski. In this correspondence, it was observed that:

“... the LMP's focus on developing a systematic and predictable process for early resolution of fundamental technical issues in the licensing of advanced reactors will reduce uncertainty in the development, design, and eventual licensing of such designs."

Chairman Svinicki's July 12, 2019, letter ${ }^{28}$ to Senator John Barrasso regarding the NRC's progress in meeting the obligations imposed by the Nuclear Energy Innovation and Modernization Act relies extensively on the work completed by the LMP to demonstrate the NRC's responsiveness to Congress. Fully a third of Enclosure $2^{29}$ of this letter "Increasing the Use of Risk-Informed and Performance-Based Evaluation techniques and Regulatory Guidance in Licensing Commercial Advanced Nuclear Reactors" directly regards the work completed by the LMP team in partnership with the DOE and NRC. The conclusions of this enclosure state:

"In 2017, the NRC staff prioritized activities to increase the use of technology-inclusive, risk-informed, and performance-based licensing approaches, where appropriate. The $N R C$ is continuing to interact with industry initiatives such as the LMP. The NRC issued DG-1353 proposing to endorse NEI 18-04, and the NRC staff is gaining experience with the application of the LMP methodology through observation of LMP tabletop exercises and the review of $L M P$ demonstration and pilot activities submitted by advanced reactor designers."

Similarly, on January 15, 2020, in oral testimony before the U.S. Senate Committee on Environment and Public Works, ${ }^{30}$ NRC Executive Director for Operations Margaret Doane stated the following: 
"Speaking of advanced reactors, the NRC has been preparing for the licensing of advanced reactors for several years, and is ready to review potential near-term applications, the first of which is anticipated this month. Notably, this past May, the staff issued a draft regulatory guide for a technology inclusive, risk-informed, and performance-based licensing approach for advanced reactor licensing. This effort was informed by the NRC's staff interactions with the Licensing Modernization Project, a DOE cost-shared initiative being led by Southern Company and coordinated by the Nuclear Energy Institute. The staff's regulatory guide will serve as a foundation for the rulemaking to establish a technology inclusive regulatory framework for advanced reactors."

This testimony is just the latest to recognize that the LMP has established the foundation for the NRC and industry to effectively modernize the development and approval of a licensing basis for advanced non-LWRs which maintains reasonable assurance of adequate protection of public health and safety. 


\section{NRC REVIEWS, DRAFTS, AND ACTIONS LEADING TO NRC ENDORSEMENT OF LMP GUIDANCE DOCUMENT}

A major objective of the LMP was that the resulting TI-RIPB guidance be endorsable by the NRC to provide increased regulatory assurance to non-LWR designers and project developers. This objective was achieved, as demonstrated by the DG-1353 issuance and ACRS's supportive reviews, through productive collaborations with the NRC staff and management.

To support the objective of formally endorsing the TI-RIPB process such that it can be used with confidence by the advanced reactor community, the NRC staff produced draft regulatory guide DG-1353 "Guidance for a Technology-Inclusive, Risk-Informed, and Performance-Based Methodology to Inform the Licensing Basis and Content of Applications for Licenses, Certifications, and Approvals for Non-LightWater Reactors." Note that DG-1353 includes endorsement of the LMP RIPB methodology and provides guidance to applicants on topics beyond the scope of NEI 18-04. In concert with DG-1353, the NRC staff also produced a draft SECY paper requesting the Commissioner's approval of the Staff's proposals for a TI-RIPB framework embodied by NEI 18-04.

The LMP-produced guidance document and the NRC staff-produced DG-1353 with associated SECY have been reviewed by the ACRS Subcommittee on Future Plant Designs twice and the ACRS Full Committee once. The February 2, 2019, ACRS Full Committee meeting including NRC staff presentation of their reviews and feedback on the LMP guidance document NEI 18-04 Draft N, the Staff's draft of DG-1353, and LMP team presentations on NEI 18-04 Draft N. The ACRS Full Committee provided their positive response in their letter report on the matter to Chairman Svinicki dated March 19, 2019. Per agency guidance, the completed NRC staff-prepared Regulatory Guide on this matter will go before the ACRS Full Committee before formal issuance.

In recognition of the NRC's chartered duty to protect public health and safety with transparency appropriate for the topic involved, on May 3, 2019, the NRC provided notification in the Federal Register ${ }^{31}$ of a public comment period on draft regulatory guide DG-1353. This public comment period ended on July 2, 2019, with one public comment. This comment focused on the well-known aspect of PRA regarding the division or consolidation of individual event sequences into event sequence families. Such topic is addressed in the current ASME/ANS RA-S-1.4-2013, "Probabilistic Risk Assessment Standard for Advanced Non-LWR Nuclear Power Plants." Upon review of the comment, LMP team members do not believe any changes to NEI 18-04 are required and that the NRC staff has ample justification for finding the comment non-persuasive regarding the content of DG-1353. As of the date of this report, the formal NRC staff response is outstanding.

On December 2, 2019, the Staff issued SECY-19-0117 “Technology-Inclusive, Risk-Informed, and Performance-Based Methodology to Inform the Licensing Basis and Content of Applications for Licenses, Certifications, and Approvals for Non-Light-Water Reactors" to the Commissioners requesting Commission approval of the use of the TI-RIPB LMP methodology via Notation Vote. As of the date of this report, the Commissioners' formal votes on SECY-19-0117 remain outstanding.

Table 7 lists the NRC-produced documents regarding endorsement of NEI 18-04 as documented in ADAMS, and Table 8 provides the NRC endorsement process timeline. 
Table 7. NRC-Produced Documents Regarding Endorsement of NEI 18-04 in NRC ADAMS

\begin{tabular}{|c|c|c|}
\hline $\begin{array}{l}\text { Document } \\
\text { Date }\end{array}$ & $\begin{array}{l}\text { Associated ADAMS } \\
\text { Accession Number }\end{array}$ & Subject \\
\hline 08/16/2018 & ML18226A212 & $\begin{array}{l}\text { DG-1353 "Guidance for a Technology-Inclusive, Risk-Informed, and } \\
\text { Performance-Based Methodology to Inform the Licensing Basis } \\
\text { and Content of Applications for Licenses, Certifications, and } \\
\text { Approvals for Non-Light-Water Reactors" working draft. }\end{array}$ \\
\hline $09 / 28 / 2018$ & ML18271A164 & $\begin{array}{l}\text { DG-1353 "Guidance for a Technology-Inclusive, Risk-Informed, and } \\
\text { Performance-Based Methodology to Inform the Licensing Basis } \\
\text { and Content of Applications for Licenses, Certifications, and } \\
\text { Approvals for Non-Light-Water Reactors" working draft. }\end{array}$ \\
\hline 09/28/2018 & ML18270A334 & Un-numbered working draft SECY regarding DG-1353. \\
\hline 04/30/2019 & ML18312A242 & $\begin{array}{l}\text { Draft Regulatory Guide DG-1353 "Guidance for a Technology-Inclusive, } \\
\text { Risk-Informed, and Performance-Based Methodology to Inform the } \\
\text { Licensing Basis and Content of Applications for Licenses, Certifications, } \\
\text { and Approvals for Non-Light-Water Reactors." Note that this version } \\
\text { was provided for public review during the May } 3 \text { through July 2, 2019, } \\
\text { public comment period noticed in the Federal Register and provided on } \\
\text { https://www.regulations.gov. }\end{array}$ \\
\hline $04 / 30 / 2019$ & ML18337A214 & Regulatory Analysis of DG-1353. \\
\hline 06/06/2019 & ML19158A457 & Mr. Richard Denning public comment in response to DG- 1353. \\
\hline 08/01/2019 & ML19261B955 & $\begin{array}{l}\text { Miscellaneous Material Related to DG-1353 on Licensing Basis for Non- } \\
\text { LWRs [(1) Email and Attachment from M Tschiltz (NEI) regarding public } \\
\text { comment received on DG-1353; (2) Email and Attachment on } \\
\text { clarification/background on F-C target points in support of NGNP and } \\
\text { NEI 18-04 (which is proposed to be endorsed in DG-1353)]. }\end{array}$ \\
\hline $11 / 21 / 2019$ & ML19325C089 & $\begin{array}{l}\text { Draft Outline for Licensing Modernization Project Advanced Reactor } \\
\text { License Application. }\end{array}$ \\
\hline $12 / 02 / 2019$ & ML18311A264 & $\begin{array}{l}\text { SECY-19-0117: Technology-Inclusive, Risk-Informed, and Performance- } \\
\text { Based Methodology to Inform the Licensing Basis and Content of } \\
\text { Applications for Licenses, Certifications, and Approvals for Non-Light- } \\
\text { Water Reactors. NRC ADAMS accession number ML18311A264 is a } \\
\text { folder containing letter ML18312A253 and letter enclosure } \\
\text { ML18312A313. }\end{array}$ \\
\hline
\end{tabular}




\section{Table 8. NRC Endorsement Process Timeline}

\begin{tabular}{|c|c|c|}
\hline Date & Item & Activity \\
\hline 06/19/2018 & $\begin{array}{l}\text { NRC staff/ACRS Subcommittee on } \\
\text { Future Plant Designs meeting }\end{array}$ & Complete - See Table 5 for details. \\
\hline $10 / 31 / 2018$ & $\begin{array}{l}\text { NRC staff/ACRS Subcommittee on } \\
\text { Future Plant Designs meeting }\end{array}$ & Complete-See Table 5 for details. \\
\hline 02/06/2019 & $\begin{array}{l}\text { NRC staff/ ACRS Full Committee } \\
\text { meeting }\end{array}$ & Complete-See Table 5 for details. \\
\hline $\begin{array}{l}05 / 03- \\
07 / 02 / 2019\end{array}$ & NRC Public Comment Period & Complete-See text above and Table 7 for details. \\
\hline 08/26/2019 & $\begin{array}{l}\text { LMP production of NEI 18-04 } \\
\text { Rev } 1\end{array}$ & $\begin{array}{l}\text { Complete-The LMP guidance document NEI 18-04 was } \\
\text { updated to Rev } 1 \text { and transmitted to NEI as a complete, } \\
\text { non-draft document incorporating lessons learned from } \\
\text { industry demonstrations, ACRS meetings, and the public } \\
\text { comment period. On August } 26,2019 \text {, NEI transmitted a } \\
\text { letter to the NRC requesting NRC endorsement of NEI 18-04 } \\
\text { Rev } 1 .\end{array}$ \\
\hline $12 / 02 / 2019$ & SECY-19-0117 & $\begin{array}{l}\text { SECY transmitted from the NRC Staff to the Commissioners } \\
\text { requesting Commission approval of the use of the TI-RIPB } \\
\text { LMP methodology via Notation Vote. }\end{array}$ \\
\hline $\begin{array}{l}\text { TBD - } \\
\text { Projected } \\
2020\end{array}$ & $\begin{array}{l}\text { NRC staff resolution of DG-1353 } \\
\text { public comments }\end{array}$ & $\begin{array}{l}\text { The NRC staff continues to prepare their response to the } \\
\text { one public comment received on DG- } 1353 \text { and } \\
\text { accompanying draft SECY. The LMP team does not expect } \\
\text { the resolution of the public comment to have any impact on } \\
\text { the content of NEI 18-04 Rev } 1 \text {. }\end{array}$ \\
\hline $\begin{array}{l}\text { TBD - } \\
\text { Projected } \\
2020\end{array}$ & $\begin{array}{l}\text { NRC Commissioner's publication } \\
\text { of Staff Requirements } \\
\text { Memoranda for SECY-19-0117 } \\
\text { regarding Staff TI-RIPB approach }\end{array}$ & $\begin{array}{l}\text { The NRC staff has provided SECY-19-0117 to the } \\
\text { Commissioners seeking approval of the NRC staff's } \\
\text { proposed approach for implementing the LMP RIPB } \\
\text { framework. The Commission has not yet completed voting } \\
\text { on the matter. }\end{array}$ \\
\hline $\begin{array}{l}\text { TBD - } \\
\text { Projected } \\
2020\end{array}$ & $\begin{array}{l}\text { ACRS Full Committee meeting on } \\
\text { Regulatory Guide }\end{array}$ & $\begin{array}{l}\text { As per NRC processes, the completed NRC staff-prepared } \\
\text { Regulatory Guide on this matter will go before the ACRS Full } \\
\text { Committee before formal issuance. }\end{array}$ \\
\hline $\begin{array}{l}\text { TBD - } \\
\text { Projected } \\
2020\end{array}$ & $\begin{array}{l}\text { Issuance of NRC Regulatory } \\
\text { Guide/Guidance Document } \\
\text { Endorsement }\end{array}$ & $\begin{array}{l}\text { DG-1353 will be finalized and released as a regulatory guide } \\
\text { that formally endorses NEI 18-04 Rev } 1 \text { for use in non-LWR } \\
\text { licensing. }\end{array}$ \\
\hline
\end{tabular}




\section{PROJECT COMPLETION}

This report completes all the project's contractual deliverables to INL. The LMP team recognizes that further work in the area of TI-RIPB regulation will follow and that this report will be of benefit to those who take the next steps, just as the high quality and retrievable documentation of the NGNP project was of vital assistance in maximizing the efficiency of the LMP. 


\section{SUGGESTED FUTURE ACTIONS}

The LMP is a significant advancement in the state of U.S. licensing of non-LWRs. Multiple leading nonLWR designers are employing the LMP methodology as part of their licensing plans. Notably, the team advancing the planned DOE Versatile Test Reactor has publicly embraced the LMP methodology and is implementing the LMP RIPB process in that industry-leading effort. ${ }^{32}$ Further work building on the LMP foundation would be expected to deliver additional regulatory certainty sought by reactor designers and project developers.

The primary suggested action is the completion of the Technology Inclusive Content of Application Project (TICAP) initiated in late 2019. TICAP is envisioned as a utility-led collaborative effort with the ARRTF and NRC to develop a technology-inclusive formulation for preparing the content of applications for NRC licenses and certifications that is versatile, systematic, and compatible with the NRC's mission of protecting the public. The proposed deliverable of TICAP is a document that outlines the content of an application in a manner that is technology-inclusive, uses LMP methodology, and can be submitted to NRC for endorsement within two calendar years of project initiation.

In light of the NRC Staff's similar perspective regarding furthering the work of the LMP to inform the content of future applications, on November 21, 2019, the Staff issued their "Draft Outline for Licensing Modernization Project Advanced Reactor License Application" ${ }^{33}$ for discussion. While the content of this draft was not coordinated with nor endorsed by the LMP team, it clearly reflects the NRC Staff's expectation of implementation of the LMP process by future applicants.

${ }^{1}$ U.S. Nuclear Regulatory Commission, "NRC Vision and Strategy: Safely Achieving Effective and Efficient Non-Light Water Reactor Mission Readiness," ML16356A670, December 2016.

2 U.S. Nuclear Regulatory Commission, “NRC Non-Light Water Reactor Near-Term Implementation Action Plans," ML17165A069, July 2017.

${ }^{3}$ U.S. Nuclear Regulatory Commission, "NRC Non-Light Water Reactor Mid-Term and Long-Term Implementation Action Plans," ML17164A173, July 2017.

${ }^{4}$ U.S. Nuclear Regulatory Commission, "Report to Congress: Advanced Reactor Licensing, U.S. Nuclear Regulatory Commission,” August 22, 2012.

${ }^{5}$ W. Moe, "Regulatory Risk Reduction for Advanced Reactor Technologies-FY 2016 Status and Work Plan Summary," INL/EXT-16-39629, DOE:10.2172/1364483, September 2016.

${ }^{6}$ W. Moe, "Regulatory Risk Reduction for Advanced Reactor Technologies: FY 2017 Framework Modernization Proposals and Status," INL/EXT-17-42791, DOE: 10.2172/1408735, August 2017.

${ }^{7}$ W. Moe, "Licensing Modernization Project for Advanced Reactor Technologies: FY 2018 Project Status Report," INL/EXT-18-46151, DOI:10.2172/1471714, September 2018.

${ }^{8}$ Nuclear Energy Institute, "NEl Activities in Support of Advanced Non-Light Water Reactors," Washington, DC., NRC ADAMS ML17013A138, January 11, 2017.

${ }^{9}$ W. Moe and J. Kinsey, "NRC Licensing Status Summary Report for NGNP," INL/EXT-13-28205, Rev 1, DOE:10.2172/1236815, November 2014. 
${ }^{10}$ Southern Company, "Modernization of Technical Requirements for Licensing of Advanced Non-LightWater Reactors: Selection of Licensing Basis Events," SC-29980-100, Rev A, April 2017.

${ }^{11}$ Idaho National Laboratory, "Next Generation Nuclear Plant Licensing Basis Event Selection White Paper," INL/EXT-10-19521, DOI:10.2172/991912, September 2010.

${ }^{12}$ Southern Company, "Modernization of Technical Requirements for Licensing of Advanced Non-Light Water Reactors: Safety Classification and Performance Criteria for Structures, Systems, and Components," SC-29980-102 Rev B, April 2018.

${ }^{13}$ Idaho National Laboratory, "Next Generation Nuclear Plant Structures, Systems, and Components Safety Classification White Paper," INL/EXT-10-19509, DOI:10.2172/991911, September 2010.

${ }^{14}$ U.S. Nuclear Regulatory Commission, "Historical Review and Observations of Defense-in-Depth," NUREG/KM-0009, ADAMS ML16104A071, April 2016.

${ }^{15}$ International Atomic Energy Agency, "Assessment of Defense in Depth for Nuclear Power Plants," Safety Reports Series No. 46, ISBN:92-0-114004-5, 2005.

${ }^{16}$ Southern Company, "Modernization of Technical Requirements for Licensing of Advanced Non-Light Water Reactors: Risk-Informed and Performance-Based Evaluation of Defense-in-Depth Adequacy," SC-29980-103, Rev A, May 2018.

${ }^{17}$ Southern Company, "Modernization of Technical Requirements for Licensing of Advanced Non-LightWater Reactors: Probabilistic Risk Assessment Approach," SC-29980-101, Rev A, June 2017.

${ }^{18}$ American Society of Mechanical Engineers and American Nuclear Society, "Probabilistic Risk Assessment Standard for Advanced non-LWR Nuclear Power Plants," RA-S-1.4-2013.

${ }^{19}$ Letter from Louis Lund, NRC Standards Executive, U.S. Nuclear Regulatory Commission to C. Rick Grantom, Co-Chair and Bob Budnitz Co-Chair, ASME/ANS Joint Committee on Nuclear Risk Management, "NRC Plan for Endorsement of ASME/ANS Advanced non-LWR PRA Standard," Adams Accession Number 20045G141, March 13, 2013.

${ }^{20}$ Oklo, Inc., Submittal of DG-1353 Pilot, ADAMS ML18282A003, October 31, 2018.

${ }^{21}$ Oklo, Inc. Draft Guide 1353 Pilot Report - Redacted. September 30, 2018. NRC ADAMS ML19038A473.

${ }^{22}$ Nuclear Energy Institute, NEI 18-04, "Risk-Informed Performance-Based Technology Inclusive Guidance for Advanced Reactor Licensing Basis Development," Rev 0, DOI:10.2172/1557649, April 1, 2019.

${ }^{23}$ Tschiltz, Michael D., "Request for NRC Endorsement of NEI 18-04, Rev 1," ADAMS ML19241A333, August 26, 2019.

${ }^{24}$ Nuclear Energy Institute, NEI 18-04, "Risk-Informed Performance-Based Technology Inclusive Guidance for Non-Light Water Reactor Licensing Basis Development," Revision 1, ADAMS ML19241A472, August 26, 2019.

${ }^{25}$ M200206: Scheduling Note and Slides - Briefing on Advanced Reactors and New Reactor Topics; Commission Meeting Agenda and Slides, ADAMS ML20038A184, February 6, 2020.

${ }^{26}$ Brown, Fredrick D., "Licensing Modernization Project," ADAMS ML18047A149, February 21, 2018.

${ }^{27}$ Kuczynski, Stephen E., "Re: Licensing Modernization Project," ADAMS ML18103A213, March 9, 2018. 
${ }^{28}$ Svinicki, K., "Reports to Congress on Establishing Steps in the Advanced Reactor Licensing Process and Increasing the Use of Risk-Informed and Performance-Based Evaluation Techniques and Regulatory Guidance, Required by the Nuclear Energy Innovation and Modernization Act," ADAMS ML19128A289, July 12, 2019.

${ }^{29}$ Svinicki, K., "Enclosure 2 - Report to Congress on Increasing Use of Risk-Informed and PerformanceBased Evaluation Techniques and Regulatory Guidance in Licensing Commercial Advanced Nuclear Reactors," ADAMS ML19128A324, July 12, 2019.

${ }^{30}$ Doane, Margaret. Oral testimony before the US Senate Committee on Environment and Public Works. January 15, 2020. Transcript and archived video available at: https://www.epw.senate.gov/public/index.cfm/2020/1/one-year-of-progress-an-update-onimplementation-of-the-nuclear-energy-innovation-and-modernization-act

${ }^{31}$ Nuclear Regulatory Commission. [NRC-2019-0113] “Guidance for a Technology-Inclusive, RiskInformed, and Performance-Based Methodology to Inform the Licensing Basis and Content of Applications for Licenses, Certifications, and Approvals for Non-Light Water Reactors," Federal Register Volume 84, No. 86, Page 19132. May 3, 2019.

${ }^{32}$ David Grabaskas, Jason Andrus, Dennis Henneke, Matthew Bucknor, Jonathan Li, Doug Gerstner, Matthew Warner, Thomas Fanning. Application of the Licensing Modernization Project Approach to the Authorization of the Versatile Test Reactor. American Nuclear Society Transactions; Volume 121; Number 1; November 2019; Pages 1396-1398. https://dx.doi.org/10.13182/T31287.

${ }^{33}$ Nuclear Regulatory Commission. "Draft Outline for Licensing Modernization Project Advanced Reactor License Application.” ADAMS ML19325C089; November 21, 2019. 
APPENDIX A - FEBRUARY 6, 2020 COMMISSION BRIEFING SLIDES REGARDING LICENSING MODERNIZATION PROJECT (LMP) DELIVERED BY AMIR AFZALI, LICENSING AND POLICY DIRECTOR, SOUTHERN COMPANY 


\title{
Licensing Modernization Project (LMP)
}

\author{
Amir Afzali \\ Licensing and Policy Director \\ Southern Company
}




\section{Licensing Modernization Project}

Why: Reduce regulatory uncertainty to enable accelerated commercialization of advanced non-LWR reactors

- Consistent with the Commission's long-standing effort to transition to risk-informed, performance-based regulations

- Key to achieving modern risk-informed regulation as envisioned in the agency's Transformation Initiative.

How: Develop transparent, systematic, risk-informed, performancebased, and predictable methodology

What: NEI 18-04 and four supporting reports are intended to:

- Select and evaluate Licensing Basis Events (LBEs)

- Classify Structures, Systems and Components (SSCs) based on their holistic and realistic contribution to risk

- Determine Defense-in-Depth (DiD) adequacy 


\section{LBE Evaluation Chart}

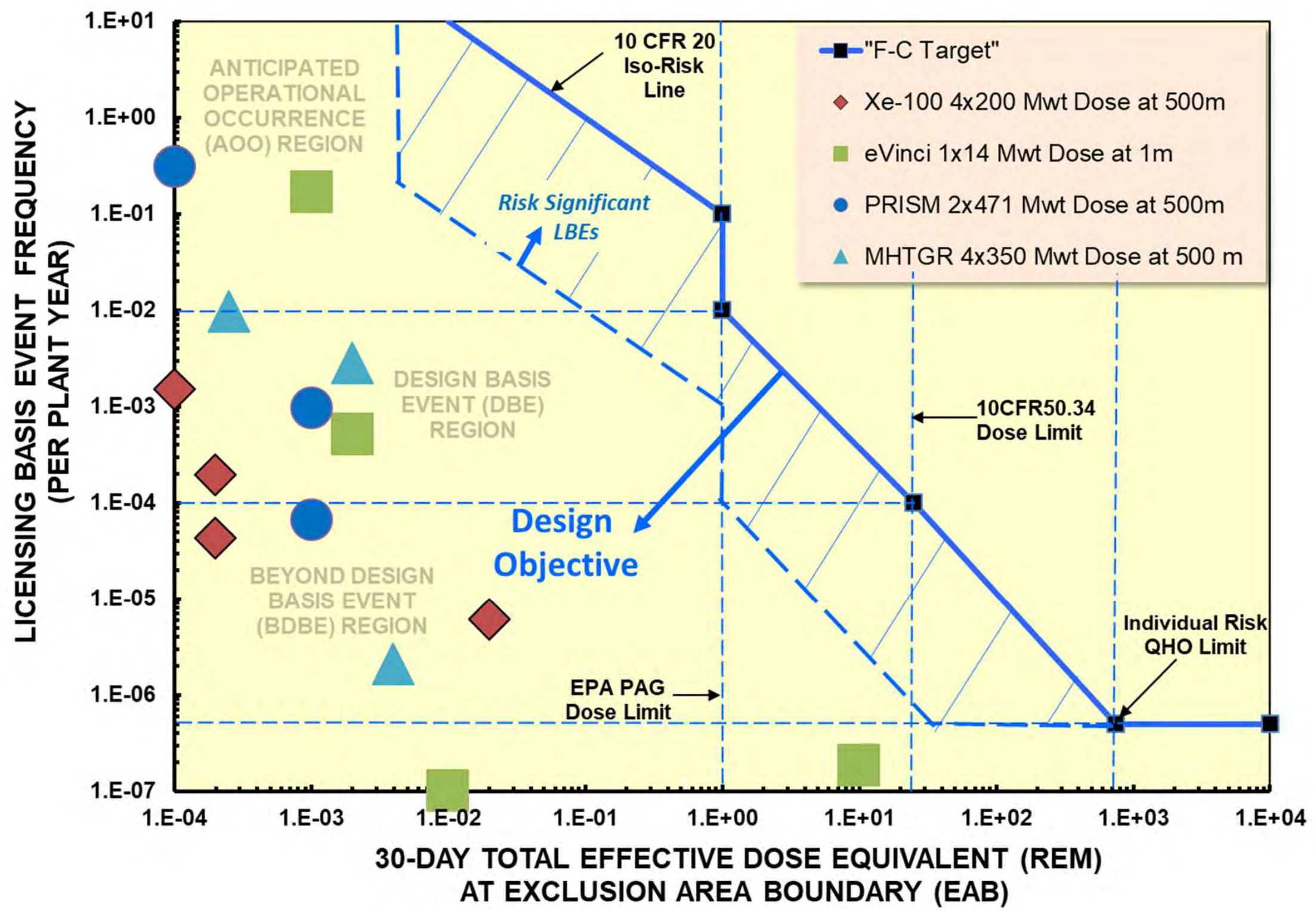




\section{LMP Tabletop Insights}

Results of the Tabletop exercises confirmed that:

- The LMP process can be effectively executed for a spectrum of different non-LWR concepts

- Design decisions can be optimized through an integrated and realistic analysis of the plant's response

- Information obtained through the LMP-based design evaluation can be used for building a strong operational risk management program 


\section{Summary}

- The LMP methodology, presented in NEI 18-04, is developed based on:

- over 20 years of industry interactions with the NRC staff on risk-informed regulatory approaches, including many public reviews and discussions

- lessons learned from a number of industry tabletop exercises, covering different technologies and designs

- Positive support of Draft Guide-1353 which endorses NEI 18-04:

- ACRS letter of support, following a number of meetings with the industry and NRC staff.

- Next steps:

- Critical- Approval of SECY-19-0117

- Valuable- NRC endorsement of ASME non-LWR PRA standard.

SECY-19-0117 key step in support of Commission's longstanding effort to transition to risk-informed, performance-

based regulations and regulatory modernization 


\section{Acronyms}

- LMP- Licensing Modernization Project

- NEI- Nuclear Energy Institute

- LBE- Licensing Basis Events

- DBE- Design Basis Events

- DBA- Design Basis Accidents

- BDBE- Beyond Design Basis Events

- DiD- Defense-in-Depth

- QHO- Quantitative Health Objective

- EPA- Environmental Protection Agency

- PAG- Protection Active Guide

- EAB- Exclusion Area Boundary

- Mwt- Megawatt Thermal

- F-C-Frequency-Consequence 


\section{APPENDIX B - SPEAKER'S NARRATIVE FOR FEBRUARY 6, 2020 COMMISSION BRIEFING REGARDING LICENSING MODERNIZATION PROJECT (LMP) DELIVERED BY AMIR AFZALI, LICENSING AND POLICY DIRECTOR, SOUTHERN COMPANY}

\section{Licensing Modernization Project (LMP)- Technology Inclusive Risk-Informed/Performance-Based Foundation for Demonstrating Regulatory Compliance}

\section{Slide 1-}

Good morning. My name is Amir Afzali. I am the Licensing and Policy Director for Advanced Reactors at Southern Company. Thank you for affording me the opportunity to talk to you about the licensing modernization project. LMP was initiated to develop a Technology Inclusive RiskInformed/Performance-Based (TI RIPB) foundation for modernizing regulatory requirements for nonLWRs.

The project has led to generation of NEI 18-04, which the Staff has proposed to be endorsed in SECY-190117. In the next few slides I will discuss why LMP was initiated, how its scope was defined, and the products that were generated. I will then discuss the LMP's proposed frequency-consequence curve (FC) and I will wrap up by sharing a couple of key insights from some of the LMP's tabletop exercises and provide a brief summary.

\section{Slide 2-}

The LMP objective is to reduce regulatory uncertainties for both designers and regulators to enable accelerated commercialization of advanced non-LWR reactors, while maintaining public health and safety.

The LMP team believes the most effective approach for delivering this objective is through utilization of risk-informed/performance-based methodologies. We also believe that such an approach is an important step toward achieving the Commission's long-held goal of advancing the application of risk insights in the realization and demonstration of nuclear safety.

To deliver project's objective, the team focused on developing a transparent, repeatable, and RIPB methodology to decide on the following key foundations of a design safety case

- Selection of Licensing Basis Events (LBEs). The current regulatory guidance does not include a method for identifying LBEs for a non-LWR-based-design. Such events include Anticipated Operational Occurrences (AOOs), Design Basis Events (DBEs), and Beyond Design Basis Events (BDBEs).

These events, which form the foundation of a design safety basis, will be different for each design based on the underlying technology and design specific features.

Therefore, developing a technology inclusive method for the LBE selection is expected to result in significant reduction in regulatory uncertainty. 
- Classification of Structures, Systems, and Components (SSCs)- Based on the lessons learned from application of the RIPB method for SSC categorization of the LWR-designs, it was judged that a comparable process for SSC classification at the original licensing stage will be beneficial for both the regulator and future licensees.

- Defense-in-Depth adequacy determination- The lessons learned from previous licensing activities have demonstrated the need for a method which provides clarity and transparency in the determination of DiD adequacy. Therefore, this foundational element was also included in the project's scope.

Due to time limitations and the importance of the LBE section methodology, for the rest of the presentation I will discuss a few important features of the LBE selection process.

Slide 3-

The LMP methodology is premised on a Frequency-Consequence chart that underpins the systematic evaluation of LBEs in the context of appropriate individual LBEs and total risk targets. Targets are based on an interpretation of the NRC regulatory requirements and the Commission's Safety Goal Policy.

One of the most unique and insightful features of the methodology is the clear demonstration of the design margins for a particular design. These margins are exhibited through the gaps between each LBE's associated frequency and consequence for a design and the frequency-consequence targets (shown by the bold blue line).

To confirm the practicality of the methodology, the following developers and organizations exercised portions of the methodology:

- X-energy, for Xe-100, a high temperature gas-cooled, pebble-bed TRISO fuel reactor design,

- General Electric-Hitachi, for PRISM, a sodium-cooled, metallic fuel reactor design,

- Kairos, for a molten salt-cooled, pebble-bed TRISO fuel design,

- Westinghouse Electric, for eVinci, a heat pipe cooled, solid metallic fuel micro reactor design, and

- EPRI/Vanderbilt University, for the Molten Salt Reactor Experiment, a molten salt cooled and molten salt fuel reactor design.

This slide presents the results of some of these exercises as well as previous results for a prototype modular high temperature gas-cooled reactor (HTGR) plant. Please note the anticipated margins to the regulatory targets for these designs.

A couple of key insights from these exercises are offered in the next slide. For now, I would like to highlight that each point on the frequency-consequence curve is the result of a careful evaluation of the potential class of hazards that could challenge the safety performance of a design, the design's capabilities to respond to those hazards, and performance requirements of these plant capabilities to provide reasonable assurance of success. 
Slide 4-

The following are a couple of key insights from the tabletop exercises:

- the LMP process can be effectively executed for a spectrum of different non-LWR concepts, from large reactors to micro reactors. This indicates the technology inclusive nature of the proposal.

- design decisions can be optimized through an integrated and realistic analysis of the plant response. This is important for maximizing safety while minimizing unnecessary burden.

In addition to these direct observations, and based on our experience in the use of RIPB regulation for the current fleet, we have concluded that the knowledge gained through the LMP-based design evaluation will be used for building an effective operational risk management program.

\section{Slide 5-}

In summary, the LMP methodology, as presented in NEI 18-04, was developed based on over 20 years of industry interactions with the staff on risk-informed regulatory approaches. The insights from a number of industry tabletop exercises, covering different technologies and designs, demonstrated that the methodology can be effectively executed for a spectrum of different non-LWR concepts.

We are also reassured by the fact that the ACRS letter on draft guide 1353 finds that the methodology is reasonable.

The desired next steps for enabling timely and effective deployment of the LMP methodology include the following critical and valuable actions:

- Commission agreeing with the Staff's position, as documented in SECY-19-0117, that the NEI 1804 methodology is reasonable and appropriate. We believe that such an endorsement is a critical step in enabling the Commission's long-standing effort to transition to risk-informed, performance-based regulations and is key to achieving modern risk-informed regulation as envisioned in the agency's Transformation Initiative.

- $\quad$ NRC endorsement of ASME non-LWR PRA standard. We believe this endorsement will reduce the NRC's review time as well as reducing uncertainty.

Thank you again for allowing me to discuss this important industry initiative on the behalf of the LMP team. 